\title{
Offshoring and job stability: Evidence from Italian manufacturing
}

\author{
Alessia Lo Turco ${ }^{a}$, Daniela Maggioni ${ }^{\mathrm{a}, *}$, Matteo Picchio ${ }^{\mathrm{a}, \mathrm{b}, \mathrm{c}, \mathrm{d}}$ \\ a Marche Polytechnic University, Department of Economics and Social Sciences, Italy \\ b Tilburg University, CentER, The Netherlands \\ c Ghent University, Sherppa, Belgium \\ d IZA, Germany
}

\section{A R T I C L E I N F O}

\section{Article history:}

Received May 2012

Received in revised form February 2013

Accepted April 2013

Available online $\mathrm{xxx}$

\section{JEL classification:}

C41

F14

F16

J62

\section{Keywords:}

Offshoring

Job stability

Manufacturing

Duration analysis

Proportional hazard

\begin{abstract}
A B S T R A C T
We study the relationship between offshoring and job stability in Italy in the period 1995-2001 by using an administrative dataset on manufacturing workers. We find that the international fragmentation of production negatively affects job stability. Service offshoring and material purchases from developed countries foster job-to-job transitions within manufacturing of all workers and white collars, respectively. However, the most detrimental effects for job stability come from material offshoring to low income countries which drives blue collar workers out of manufacturing. Therefore, policy interventions should especially focus on this latter category of workers more exposed to fragmentation processes and foreign competition
\end{abstract}

(c) 2013 Elsevier B.V. All rights reserved.

\section{Introduction}

In the last decades low labour cost countries have gained a growing role in the process of international fragmentation of production. At the same time, the rapid spread of ICTs across the world has favoured the tradability of some service activities. These phenomena have raised concerns about job security, especially of low skill workers and employees performing routinely and simple tasks, as they might be more exposed to the process of international

\footnotetext{
* Corresponding author at: Marche Polytechnic University, Department of Economics and Social Sciences, Piazzale Martelli 8, 60121 Ancona, Italy. Tel.: +39 0712207250 ; fax: +39 2207102.

E-mail addresses: a.loturco@univpm.it (A. Lo Turco), d.maggioni@univpm.it (D. Maggioni), m.picchio@univpm.it (M. Picchio).
}

fragmentation of production. As a consequence, a large strand of the theoretical and empirical literature on trade and labour has tried to understand the impact of offshoring of materials and services on the equilibrium employment, the skill upgrading, and the wage differentials between high skill and low skill workers. ${ }^{1}$

Although the short run dynamics generated by offshoring might be extremely policy relevant and their analysis might help to dampen the associated adjustment costs, the theoretical literature has not devoted much attention to them. The offshoring of production phases or tasks may result in cost saving, productivity improvements,

\footnotetext{
${ }^{1}$ See Feenstra and Hanson $(1996,1999)$ and Amiti and Wei (2004) for seminal contributions in this field.
} 
and expansion of the output and of the relative demand of the factor more intensively used in the offshoring sector (Arndt, 1997; Grossman and Rossi-Hansberg, 2008). However, these productivity gains from offshoring are not always compared to the short run welfare losses generated by the possible rise in unemployment and job transitions. The short run effects, modelled by means of low or no inter-sector mobility in two sector models, highlight the theoretical possibility of increased unemployment from offshoring in the offshoring sector (Mitra and Ranjan, 2007, 2010). It is essentially an empirical matter to ascertain whether and to what extent an increase in offshoring intensity causes an increase in job dismissals and, consequently, a reduced job stability. This is a relatively less researched area consisting of very recent studies providing evidence about the effects of foreign competitive pressures on employees' probability of retaining their jobs (Egger et al., 2007; Geishecker, 2008; Baumgarten, 2009; Munch, 2010; Bachmann and Braun, 2011).

Within this framework, this paper is aimed at empirically exploring the effect of offshoring on job stability. We match sector level measures of offshoring with employees' information on job durations and we test whether offshoring of materials and knowledge intensive business services (KIBS) affects the job stability in Italian manufacturing sectors. Administrative data on job matches are informative about employees' characteristics and destination states in case of job separation. We exploit this rich piece of information to understand whether the impact of offshoring is heterogeneous between white and blue collar workers and whether transitions out of manufacturing and transitions to different manufacturing jobs are differently affected by offshoring. This second part of the analysis also sheds light on inter sectoral reallocations of workers. As high adjustment costs are often associated with such reallocations, we provide policy advice to design interventions which are effective in cushioning such costs.

A further contribution of our study consists in understanding whether the effect of offshoring on job stability depends on the origin country of intermediates. Whereas offshoring to low labour cost countries may represent a cost saving strategy involving the relocation of the more labour intensive phases of production, offshoring to high income economies may actually hide the search for technology improvements which may turn into an important complement for the domestic labour. Also, the skill intensity of imports increases with the human capital abundance and, thus, with the income level of the origin countries (Fitzgerald and Hallak, 2004; Schott, 2003). As a consequence, a different pattern of substitutability may follow according to the input origin, with white and blue collars being more threatened by imports from high and low income countries respectively.

We find, indeed, that purchases of foreign intermediates from developing countries reduce employees' job stability. Material offshoring to low income economies raises blue collars' probability of experiencing a transition out of manufacturing. Intermediate purchases from high income countries foster instead white collar workers' job-to-job transitions within manufacturing. Offshoring of KIBS has a similar positive effect on the job-to-job transitions of all workers.

This article is organized as follows. Section 2 reviews the literature dealing with the labour market impact of trade openness and offshoring. Section 3 presents the data, the sample and some descriptive evidence of job exit rates and offshoring in Italian manufacturing. Section 4 describes the econometric model for analysing the impact of offshoring on job stability. The estimation results are presented and commented in Section 5. Section 6 concludes.

\section{Literature review}

The theoretical and empirical literature on offshoring and the labour market has mainly focused on the effects of offshoring on the relative wage of high and low skilled workers (Feenstra and Hanson, 1996, 1999; Arndt, 1997; Egger and Falkinger, 2001). However, more attention has been devoted in recent time to the unemployment-trade nexus in models with labour market frictions (Davis and Harrigan, 2007; Egger and Kreickemeier, 2009, 2010; Felbermayr et al., 2008; Helpman and Itskhoki, 2010; Dutt et al., 2009). In the long run, these models predict that the equilibrium unemployment might be either positively or negatively affected by trade liberalisation. The specific role of offshoring in the short run is taken into account in a general equilibrium framework by Mitra and Ranjan (2007, 2010). Under mixed offshoring equilibrium - some firms offshore and others do not - they predict a positive link between offshoring and unemployment when the labour force is imperfectly mobile across sectors: despite its positive impact on productivity, offshoring causes cost saving and, thereby, a price reduction in the final good, so that more resources are directed to the relatively more rewarding non offshoring sector and unemployment rises in the offshoring sector. Thus, the theoretical literature suggests that, at least in the short run, offshoring may positively impact job separation rates in the offshoring sector. We aim at testing such hypothesis in a reduced form model within a partial equilibrium framework. We do not therefore address a formal test of the above mentioned general equilibrium framework and of the resulting channels through which offshoring affects unemployment, like relative prices changes and productivity improvements. We only provide evidence on the short run net effect.

Some empirical studies close to our research line adopt the same partial equilibrium approach. They exploit employee level databases to understand the relationship between trade and the individual probability of job separation. $^{2}$ For the US the evidence on manufacturing workers suggests that industry import exposure matters, but the magnitude of its effects on the firing rates and

\footnotetext{
2 Some further contributions have instead investigated the consequences of openness on job creation and destruction at the industry or firm-level (Davis and Haltiwanger, 1999; Kletzer, 2000; Klein et al., 2002; Davidson and Matusz, 2005; Nucci and Pozzolo, 2010). Although these analyses provide a general insight into the potential restructuring effects of openness, they do not fully identify the impact of openness on the probability of job separation at employee level. Studies based on employee level data are more reliable for this purpose.
} 
the duration of workers' joblessness is not big (Kruse, 1988; Hungerford, 1995). Moreover, employment stability is decreasing in the appreciation of the import exchange rate (Goldberg et al., 1999). The specific role of offshoring practices has not been explored by this piece of research.

For Europe, this literature is more recent and made up of few contributions. Egger et al. (2007) estimate employment transition probabilities between sectors by means of a dynamic fixed-effects multinomial logit approach. They find that an increase in the import share of intermediate goods negatively affects the probability of Austrian workers to stay in or change into the manufacturing sector, especially for industries with a comparative disadvantage. Munch (2010) finds that in Denmark in the period 1992-2001 offshoring marginally increases the job change hazard rate, the job separation rate, and the unemployment risk of low-skilled workers. Three studies using German data convey somehow conflicting results. Geishecker (2008) estimates a duration model exploiting monthly information on job spells from 1991 until 2000. He finds that offshoring, defined in the narrow sense (Feenstra and Hanson, 1996), significantly raises the individual risk of leaving employment and is homogeneous across educational attainments. This evidence contrasts with Bachmann and Braun's (2011) findings. Using a different administrative dataset on individual workers' employment histories recorded on a daily basis, they find that in the manufacturing sector the probability of moving to non-employment rises with offshoring only for medium-skilled and older workers. Moreover, their findings corroborate the evidence of a limited impact of offshoring on the overall job stability in the manufacturing sector and show that offshoring increases job stability in the service sector. Finally, Baumgarten (2009) analyses the relationship between offshoring and job tasks and finds that in the manufacturing sector the adverse effect of offshoring is smaller for nonroutine and interactive tasks.

Our study is in line with the latter group of works. In order to estimate a partial equilibrium reduced form empirical model for the overall impact of offshoring on job stability, we exploit microdata on individual job spells matched with sector level measures of offshoring retrieved from the input-output (IO) tables. We have information on job durations on monthly basis as in Munch (2010) and Geishecker (2008). Like them, we will also consider a broad measure of material offshoring, which includes all intermediate imports and not only imports from the same manufacturing sector. This broad measure allows for a wider set of material input-labour substitution possibilities. We focus on both material and service offshoring as in Baumgarten (2009), even if, as far as service imports are considered, our focus will be on offshoring of KIBS: we explicitly take into account the possible negative impact of imports of high skill intensive services on white collar jobs and, more generally, on the internal organization of firm production.

Finally, an important contribution of our work consists in splitting the material imports by origin country. None of the previous studies took into account that the effect of offshoring on job stability might depend on the origin country of the import flow. Nevertheless, whereas offshoring to low labour cost countries may represent a cost saving strategy involving the relocation of the more labour intensive phases of production, offshoring to high income economies may actually hide the search for technology improvements which may turn into an important complement for the domestic labour. Also, the skill intensity of imports increases with the human capital abundance and, thus, with the income level of the origin countries (Fitzgerald and Hallak, 2004; Schott, 2003). As a consequence, a different pattern of substitutability may follow according to the input origin, with white and blue collars being more threatened by imports from high and low income countries respectively. Some recent literature dealing with the effects of offshoring on the firm labour demand supports the importance of such distinction in the origin of foreign inputs. Harrison and McMillan (2007) show that imports from foreign affiliates located in low income economies reduce home employment in US multinationals, while imports from affiliates located in high income countries positively affect it. Out of the evidence on multinational firms, Lo Turco and Maggioni (2012), at the firm level for Italy, and Cadarso et al. (2008) and Falk and Wolfmayr (2008), at the industry level for Spain and the EU respectively, show a similar finding on imports from low income economies. This evidence motivates our expectations on the possibility of different offshoring effects on the job exit rate stemming from different motivations for imports, i.e. cost saving versus technology search (OECD, 2007).

\section{The data}

\subsection{The data sources and the sample}

To analyse the impact of offshoring on job security in the Italian labour market, we combine micro data on job durations and workers' characteristics with sector level data on offshoring, import penetration, technological change, efficiency, and regional proxies for the labour market conditions.

Micro data are from a longitudinal dataset provided by the Institute for the Development of Vocational Training (ISFOL) and based on the administrative records collected by the Italian Institute for National Social Security (INPS). INPS collects data on all Italian workers of the private sector through an administrative procedure based on firms' declarations. The durations of all the job spells are collected on a monthly basis. However, due to the administrative nature of the data and its collection design, when individuals exit the dataset, we do not know whether they exit to the public sector, to self-employment, to unemployment, or out of the labour force. We think, however, that this lack of information does not represent a limitation for our work, since we focus on the impact of offshoring on job transitions within and out of the manufacturing industry, regardless of the workers' destinations after they exit manufacturing. ${ }^{3}$

\footnotetext{
3 Furthermore, we are not able to distinguish between job spells ended due to the firm/plant closure from those ended for other reasons. Although the data contain variables about the firm starting and ending dates, they contain several missing values and we preferred not to use them.
} 
From all the INPS records, ISFOL collects information on every worker born on the 10th of March, June, September and December of each year. Thus, about one worker out of 91 is included in the sample. The whole dataset is composed by more than $2,470,000$ observations, which corresponds to about 963,000 job spells for about 310,000 workers in the years 1985-2002. ${ }^{4}$

From this database, we select a sample of fresh job matches which started between January 1995 and December 1998 and we follow them on a monthly basis until the end of 2001. We keep only manufacturing workers aged between 20 and 50. For each worker we retain only the first job spell in the first year the worker appears in the database. Due to the ending of the observation period in December 2001, we treat as right-censored the job spells which are not completed yet by then. ${ }^{5}$

The restriction of our sample to jobs started in the period 1995-1998 is due to two reasons. First, we cannot use older job spells since data on our main explanatory variable, offshoring, are not available before 1995. Second, we prefer not to use job spells started later than 1998, as the Italian labour market went through a series of institutional changes, mainly introducing atypical forms of job arrangements. This restriction is, therefore, aimed at avoiding job heterogeneity driven by institutional changes in the labour market.

In our analysis we also use other variables at worker level in modelling job duration distributions: the daily gross wage, the individual age, work experience calculated as the total work experience since 1985 and until sample entry, the number of previous jobs since 1985, and a set of indicators for gender, white collar, nationality, firm size, regional area, and sector. ${ }^{6}$ These variables are timeconstant and their value is fixed at the moment of entry into our sample.

Concerning the sectoral offshoring, the relative indicators are retrieved from the National import-use IO tables provided by the Italian Institute of Statistics (ISTAT). They can be computed only on a 2-digit NACE Rev. 1 sector and on yearly basis. To measure material offshoring intensity, we use a narrow indicator defined, in line with the previous literature (Feenstra and Hanson, 1996, 1999), as

$$
\begin{aligned}
& \text { OFF } \text { narrow } j t \equiv \frac{I M_{j j t}}{T I_{j t}} \times 100 \text { for } j=1, \ldots, m \text { and } \\
& t=1995, \ldots, 2001,
\end{aligned}
$$

where $I M_{j j t}$ is, for each $j$ manufacturing sector, the cost of intermediate inputs from the foreign sector $j$ at time $t$ and $T I_{j t}$ is the total of domestic and imported non energy inputs used in sector $j$. In words, this is a measure of within

\footnotetext{
4 See Centra and Rustichelli (2005) for a detailed description of the dataset. At the time of writing, we used the most recent version of the ISFOL database. Recently, ISFOL released a database update adding one year to the longitudinal dimension.

${ }^{5}$ Given the small number of observations with a complete spell longer than 60 months, we right-censor observations lasting more than 60 months in order to reduce the computational time in model estimation.

${ }^{6}$ Given the administrative nature of the data, information on education, family composition, and family background are not available.
}

industry intermediate inputs substitution, since it represents the share of intermediate purchases which is shifted to the same industry abroad.

The process of input substitution may however involve intermediates from other industries, previously produced within the boundaries of the firm or purchased from domestic suppliers. We therefore compare the performance of the narrow measure of offshoring to a broader one, which takes into account the degree of both intra and inter-industry substitution:

$O F F_{\text {broad } j t} \equiv \frac{\sum_{i=1}^{m} I M_{j i t}}{T I_{j t}} \times 100$ for $j=1, \ldots, m$.

This indicator captures the role of imports of sector $j$ from all manufacturing sectors.

Finally, in the empirical analysis we will also test the role of the offshoring of KIBS, ${ }^{7}$ which we define as

$O F F_{\text {Kibs } j t} \equiv \frac{\sum_{i=m+1}^{n} I M_{j i t}}{T I_{j t}} \times 100$ for $j=1, \ldots, m$,

where the KIBS sectors are the ones indexed by $m+1$ to $n$ in the economy.

These measures are just proxies of the offshoring phenomenon, as the imported intermediate input intensity does not exactly and exclusively capture the delocalisation of firm production phases. Nevertheless, from widespread anecdotal evidence ${ }^{8}$ and from tailored survey data (OECD, 2007), it is sensible to assume that offshoring practices may have importantly affected the recent import dynamics, especially from low labour cost countries. In the absence of better sector level indicators, we follow the literature (Feenstra and Hanson, 1996, 1999; OECD, 2007) and stick to the use of these measures.

In order to take into account the different type, quality, and technology level of inputs purchased from different trading partners, we compute the measures of material offshoring by income level of the origin countries. We follow the traditional way to construct offshoring indicators split by origin when the origin of foreign intermediates cannot be detected from the IO tables. Then, we combine IO tables with the intermediate import share by origin country for each sector. The resulting offshoring measures to high and low income countries are defined as

$$
\begin{aligned}
& O F F_{\text {narrow } j t}^{c} \equiv \frac{I M_{j i t} *\left(I M_{i t}^{c} / I M_{i t}\right)}{T I_{j t}} \times 100 \text { for } i=j \\
& O F F_{\text {broadjt }}^{c} \equiv \sum_{i}\left[\frac{I M_{j i t} *\left(I M_{i t}^{c} / I M_{i t}\right)}{T I_{j t}}\right] \times 100 .
\end{aligned}
$$

$I M_{j i}$ comes from the IO tables and measures the imported intermediates from sector $i$ used in sector $j . I M_{i}$ and $I M_{i t}^{c}$ are instead retrieved from the WITS-COMTRADE database and they respectively measure the total imports of intermediates of sector $i$ and the intermediate imports from

\footnotetext{
7 According to the definition of the EU Economic Commission (2009), KIBS are services belonging to NACE Rev. 1 sectors 72-74.

8 Several issues of the "Il Sole 24 ore" witness the offshoring process for Italian firms. As a recent example, see the 8th of October 2012 newspaper issue on Italian firms' offshoring to Serbia.
} 
country $c$, with $c=\{$ High, Low $\}$ indexing the income level of the exporting countries. ${ }^{9}$ Unfortunately, we are not able to split KIBS imports by origin, due to the difficulty to retrieve data on imported services out of the IO tables. Nevertheless, it is sensible to presume that the bulk of these imports originates from high income economies.

Our baseline specification includes further controls to account for sector and geographic time-varying heterogeneity that might affect the job exit rate, other than offshoring. At the sector level, we make use of: (i) the extent of ICT sector capital deepening, measured as the logarithm of the sectoral capital stock in office machines, telecommunication apparatus, and software over total output; (ii) the sectoral labour productivity, measured as the $\log$ of sectoral value added over the total employment; (iii) an overall measure of sectoral import penetration calculated as the percentage share of sector imports over the sum of sector output and imports minus sector exports. These variables are gathered from ISTAT National Accounts, apart from trade flows which, together with the definition of high and low income countries, are retrieved from the WITS-COMTRADE database. Finally, we use the annual regional unemployment rate gathered from ISTAT to control for the state of the labour market at regional level: Table A. 1 reports the list of all the variables used in the analysis with their definition. Table A.2 and A.3 displays summary statistics of the time-costant variables and timevarying covariates at the sample entry, respectively. Finally, Table A. 4 shows the pairwise correlations of variables at sectoral and regional level.

\subsection{Descriptive analysis}

Table 1 displays the transitions out of the current job and the job-to-job transitions by destination sector. Most of the job separations in the private sector end with a transition out of employment in the private sector ( $65 \%$ of the total exits). Focusing on the spells ending with a transition into a new job, it is more likely that the worker will be employed in the same 2-digit sector: about $58 \%$ of jobto-job transitions are within the same sector of activity.

\footnotetext{
${ }^{9}$ The definition of high and low income countries directly comes from the WITS database and is based on the World Bank country classification. In order to identify the intermediate imports (total and by country group) of each NACE sector $i$, we retained the Harmonised System (HS) import flows representing flows of intermediates according to Broad Economic Category (BEC) classification and matched them with NACE sectors by means of the HS/NACE correspondence table available in RAMON Eurostat. The BEC codes identifying intermediates are the following: 121, 122, 22,42 , and 53 . An alternative option is to use the total sector $i$ imports (of which imports of intermediates represent only one component), retrieved from WITS-COMTRADE database, in order to compute the offshoring measures split by origin countries (Cadarso et al., 2008; Falk and Wolfmayr, 2008). In this case, we assume that the weight of each country group in imports is the same for intermediates and other goods. The results obtained using these latter measures are available from the authors upon request. Finally, Schott (2004) proposed another approach: within a sector imports, intermediates are those products containing the word "part" or "component" or their abbreviations in their description. We tried to use Schott's (2004) approach. However, using the 6-digit HS, 8-digit CN, or 5 -digit SITC classifications, we ended up with a very small share of goods (less than $8 \%$ ) identified as intermediates. We preferred therefore not to follow Schott's (2004) approach.
}

Table 1

Transitions out of employment and job-to-job transitions.

\begin{tabular}{lcc}
\hline Transitions & $\begin{array}{c}\text { Absolute } \\
\text { frequency }\end{array}$ & $\begin{array}{l}\text { Relative } \\
\text { frequency (\%) }\end{array}$ \\
\hline Out of employment & 36,075 & 65.46 \\
From primary & 4947 & 8.97 \\
From manufacturing & 13,365 & 24.25 \\
From services & 17,763 & 32.23 \\
To another 2 digit NACE sector & 7935 & 14.40 \\
From primary to manufacturing & 520 & 0.94 \\
From primary to services & 1355 & 2.46 \\
From manufacturing to primary & 233 & 0.42 \\
From manufacturing to services & 1292 & 2.34 \\
From services to primary & 282 & 0.51 \\
From services to manufacturing & 1020 & 1.85 \\
Within primary & 10 & 0.02 \\
Within manufacturing & 1714 & 3.11 \\
Within services & 1509 & 2.74 \\
To the same 2 digit NACE sector & 11,101 & 20.14 \\
& & \\
Total & 55,111 & 100.00 \\
\hline
\end{tabular}

Transitions across sectors might be difficult and require important training costs for workers in order to acquire the abilities and skills which are needed to perform a job in a different sector. Nevertheless, Table 1 also shows that transitions to a different 2-digit sector are not so rare and the involved workers often move across the primary, the secondary, and the tertiary sectors. These transitions may reflect the structural change of an industrial developed economy towards more advanced, skill, and technological intensive activities - especially services - that goes with the industrial growth and international affirmation of emerging countries. This process of tertiarisation of the economy, which could be pushed and speeded up by the internationalisation of production, finds some empirical support in Table 1: when a change occurs in the main sector of activity the most important destination sector is the service sector.

An important source of heterogeneity that may affect the job stability of workers is the skill level of the job, regardless of the sector where the individual is employed. We split the workers between white and blue collars. For manufacturing, representing the focus of our empirical analysis, Fig. 1 shows employees' probability of job surviving and job exit rate by occupation. White collar workers are much more likely to preserve their job position than blue collar workers. This is consistent with the idea that low skill intensive workers are more exposed to foreign competition, economic slowdown, technological progress, and other external pressures that may drive individuals out of their occupations.

In what follows, our aim is to understand whether the process of production fragmentation across countries has significantly contributed to the above descriptive changes in job stability. In the last decades developing countries have gained a growing role in world trade of the intermediates. There has also been a further integration among developed countries stemming from the deepening of the existing relationships with foreign suppliers and customers and the increased importance of the intra-firm trade flows within multinational groups. As a consequence, Italy has experienced a growth in the shares of imported inputs 

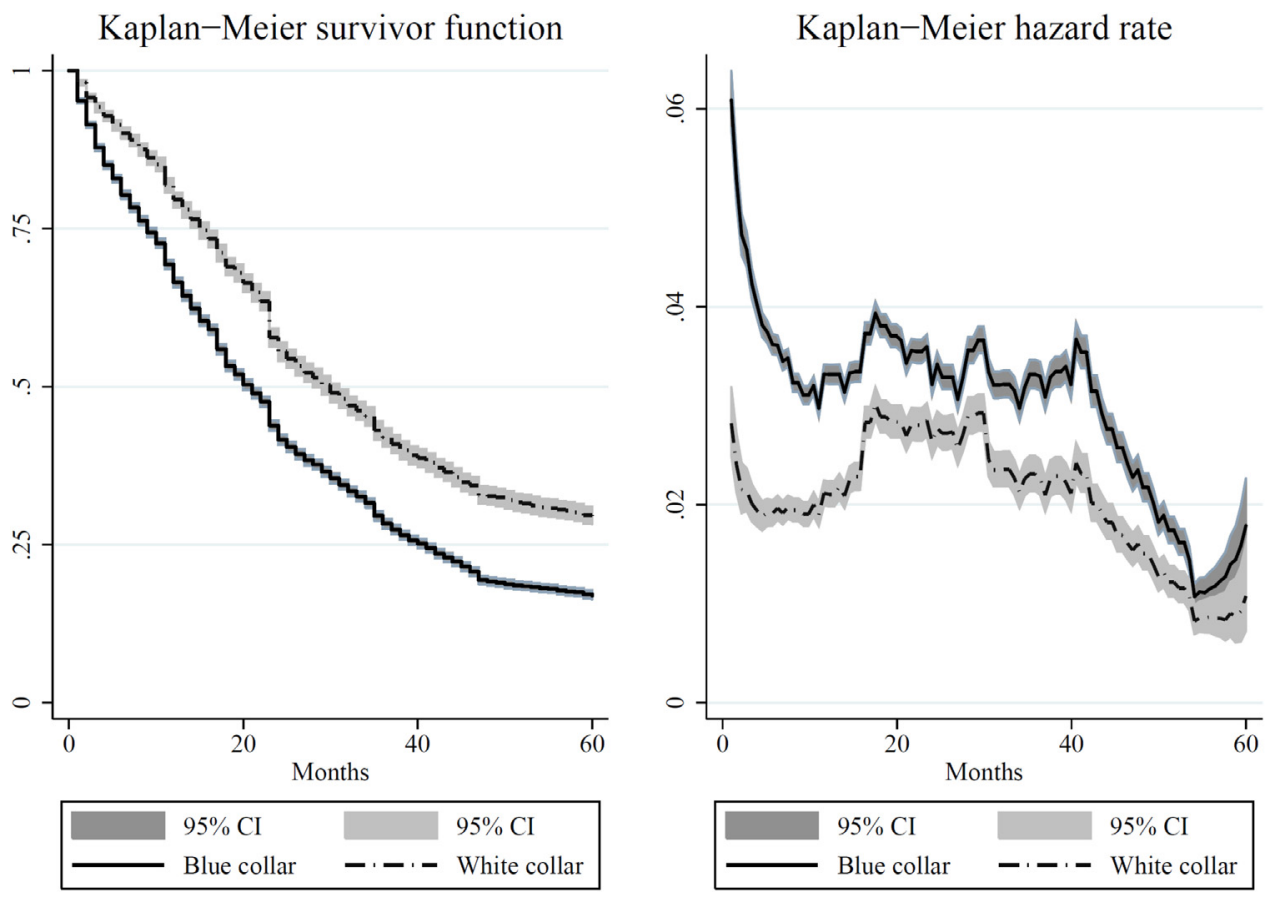

Fig. 1. Kaplan-Meier survivor and hazard functions by occupation in manufacturing sectors.

and our aim is to infer the effect of this expansion in offshoring activities on the evolution of the job stability. As we can see from Fig. A.1, in the period 1995-2004 offshoring of materials increased in most sectors, although not monotonically and with some heterogeneity. For example, in sectors Paper and paper products (NACE sector 21) and Editing and printing (NACE sector 22) material offshoring has been characterized by alternate phases of growth and drop. Instead, the purchases of intermediates from abroad significantly raised in sectors Textiles, Apparel and Leather products and footwear (NACE sectors 17-19). The picture is more clearcut if one looks at KIBS. Even in activities where the imports of material intermediates have been declining or stable, the purchase of KIBS from abroad has been expanding. This is strictly related to the worldwide rapid advances and expansion of ICTs, which have fostered the tradability of services, especially of those which are more intensive in knowledge and skills, and have driven to within-firm reorganizations of production processes. However, Fig. A.1 shows that material offshoring is still more important than knowledge intensive service offshoring in terms of magnitude of the shares.

Some further insights can be gathered by splitting the material offshoring according to the origin of inputs. Input purchases from developing countries have significantly increased in levels and with respect to the offshoring shares to developed countries. Nonetheless, high income countries are still the main partners of Italy in trade of intermediates, with shares that are greatly larger than the ones of developing countries. Only in some low skill and traditional sectors, especially Apparel and Leather products and footwear, low income countries are the most important sources of materials (see Fig. A.2).

\section{Econometric framework}

\subsection{Mixed proportional hazard job separation rates}

In order to detect the impact of offshoring on job separation rates, we estimate mixed proportional hazard (MPH) models with time-varying variables. As we only observe the labour market state occupied at the end of each month, the observed durations are measured in discrete time. We model the discrete time process as if it was generated by a grouped continuous-time model as in van den Berg and van der Klaauw (2001). By doing so, the parameters do not depend on the time unit of observation (Flinn and Heckman, 1982).

Job duration is defined as the time until the job is terminated, either because of a transition to another job or because of a transition out of employment. Let $\mathbf{x}$ denote the vector of explanatory variables which are constant over time and $\mathbf{z}$ the set of time-varying covariates. The variable $t$ (with $t \in \mathbb{N}_{0}$ ) denotes the job duration as measured from the moment of job inflow, while the variable $\tau$ (with $\tau \in \mathbb{N}_{0}$ ) denotes calendar time. The job separation rate of a spell started at time $\tau$ and after $t$ months is specified in the following MPH form

$\theta[t \mid \mathbf{x}, \mathbf{z}(\tau+t), v]=\exp \left[\alpha(t)+\boldsymbol{\beta}^{\prime} \mathbf{x}+\boldsymbol{\delta}^{\prime} \mathbf{z}(\tau+t)\right] v$

where

- $\exp [\alpha(t)]$ is the piecewise constant baseline hazard capturing the duration dependence. The time axis of each job spell is divided into $Q$ intervals $I_{q}=\left[h_{q}, h_{q+1}\right)$ with $q=1$, 
$\ldots, Q, h_{1}<h_{2}<\ldots<h_{Q}, h_{1}=1$, and $h_{Q}=\infty .{ }^{10}$ The baseline hazard function can be rewritten as

$$
\exp [\alpha(t)]=\exp \left[\sum_{q=1}^{Q} \alpha_{q} d_{q}(t)\right],
$$

where $d_{q}(t)$ is a dummy indicator equal to one if the job separation occurs during interval $I_{q}$ and $\alpha_{q}$ is the corresponding intensity parameter. ${ }^{11}$

- $\mathbf{x}$ is a $K$ dimensional vector of time-invariant covariates controlling for observed heterogeneity.

- $\mathbf{z}(\tau+t)$ is a $J$ dimensional vector of time-variant covariates, among which offshoring indexes and a set of further variables controlling for time-variant heterogeneity at the transition month $(\tau+t)$.

- $\boldsymbol{\beta}$ and $\boldsymbol{\delta}$ are the parameter vectors associated (and conformable) to the time-variant and time-invariant covariates, respectively.

- $v$ is the non-negative time-invariant individual heterogeneity which is assumed to be independent on $\mathbf{x}$ and $\mathbf{z}$.

In order to avoid strict assumptions on the distribution of the unobserved heterogeneity, we assume that $v$ has a discrete distribution like in Heckman and Singer (1984). We choose the number of points of support on the basis of information criteria (Hannan-Quinn and Akaike information criteria), as suggested by Baker and Melino's (2000) and Gaure et al.'s (2007) Monte Carlo simulations. We always end up with choosing the model with one point of support, i.e. there is evidence of no unobserved heterogeneity. More in detail, we followed Baker and Melino (2000) and Gaure et al. (2007) in searching for new mass points when moving from the model without unobserved heterogeneity to the model with unobserved heterogeneity. The starting values of the location of the new support point were chosen by looking for potential improvements in the likelihood function by maximising the Gateaux derivative. We limited the search of the starting value of the new support point over the interval $[\exp (-5), \exp (2)]$. Once we found a starting value for the location of the new support point, we set its starting probability mass to 0.0001 and we maximized the likelihood function using analytical derivatives. We were not able to increase the likelihood any further when adding new supporting points to the discrete specification of the unobserved heterogeneity distribution. In order to ensure that this result was not generated by bad initial values and convergence to a local maximum, we followed Gaure et al.'s (2007) suggestion and we restarted several times the full maximization process using random numbers as initial values for the new support point and its probability mass. Since we were never able to increase any further the likelihood, we stopped and, according to the information criteria, we chose the model with one single constant, i.e. without unobserved heterogeneity.

\footnotetext{
${ }^{10}$ We split the time axis into 9 intervals at $3,6,9,12,18,24,30$, and 36 months.

${ }^{11} \alpha_{1}$ is normalized to 0 . This normalisation is innocuous as the scale of the job separation rate is captured by $v$.
}

\subsection{The likelihood function}

In our sample we observe both complete and incomplete job spells and the data duration is measured in discrete time. We assume that the discrete time process is generated by some underlying continuous time process. Since we have monthly data, we do not exactly know when the job exit occurs within two consecutive months. We therefore assume that the job hazard rate is constant within two consecutive months. Under this assumption, it can be shown that the contribution to the likelihood function of a complete job spell started at calendar time $\tau$ and terminated after $t$ months takes the following form

$$
\begin{aligned}
L(t \mid \mathbf{x}, \mathbf{z}, v ; \Theta)= & \prod_{r=1}^{t-1} \exp \{-\theta[r \mid \mathbf{x}, \mathbf{z}(\tau+r), v]\} \\
& -\prod_{r=1}^{t} \exp \{-\theta[r \mid \mathbf{x}, \mathbf{z}(\tau+r), v]\} \\
& =\prod_{r=1}^{t-1} \exp \left\{-\exp \left[\alpha(r)+\boldsymbol{\beta}^{\prime} \mathbf{x}+\boldsymbol{\delta}^{\prime} \mathbf{z}(\tau+r)\right] v\right\} \\
& -\prod_{r=1}^{t} \exp \left\{-\exp \left[\alpha(r)+\boldsymbol{\beta}^{\prime} \mathbf{x}+\boldsymbol{\delta}^{\prime} \mathbf{z}(\tau+r)\right] v\right\} \\
& \equiv S(t-1 \mid \mathbf{x}, \mathbf{z}, v)-S(t \mid \mathbf{x}, \mathbf{z}, v),
\end{aligned}
$$

where $\Theta$ is the set of parameters to be estimated. As we specify the discrete time-process as if it was generated by a grouped continuous-time model, the contribution to the likelihood function of exiting a job spell after $t$ months is given by the difference between the probability of job surviving for $t-1$ months and the probability of surviving for $t$ months.

The contribution to the likelihood function of a job spell started at calendar time $\tau$ and incomplete after $t$ months because right censored at the end of the observation period is given by the survivor function evaluated at $t$ months:

$$
\begin{aligned}
L^{c}(t \mid \mathbf{x}, \mathbf{z}, v ; \Theta) & \equiv S(t \mid \mathbf{x}, \mathbf{z}, v)=\prod_{r=1}^{t} \exp \{-\theta[r \mid \mathbf{x}, \mathbf{z}(\tau+r), v]\} \\
& =\prod_{r=1}^{t} \exp \left\{-\exp \left[\alpha(r)+\boldsymbol{\beta}^{\prime} \mathbf{x}+\boldsymbol{\delta}^{\prime} \mathbf{z}(\tau+r)\right] v\right\}
\end{aligned}
$$

Let $c_{n}$ be an indicator variable equal to one when the job spell of individual $n$ is right censored and 0 if completed. Under the assumption that the distribution of the unobserved heterogeneity is discrete, we can integrate it out when constructing the likelihood function of individual $n$ with job duration $t_{n}$ :

$$
\begin{aligned}
\mathcal{L}_{n}\left(t_{n} \mid \mathbf{x}_{n}, \mathbf{z}_{n} ; \Theta\right)= & \sum_{m=1}^{M} p_{m}\left[L_{n}^{c}\left(t_{n} \mid \mathbf{x}_{n}, \mathbf{z}_{n}, v_{m} ; \Theta\right)\right]^{c_{n}} \\
& \times\left[L_{n}\left(t_{n} \mid \mathbf{x}_{n}, \mathbf{z}_{n}, v_{m} ; \Theta\right)\right]^{\left(1-c_{n}\right)} .
\end{aligned}
$$


The log-likelihood function sums the logarithm of Eq. (8) over all the individuals in the sample, i.e. $\mathcal{L}=$ $\sum_{n=1}^{N} \mathcal{L}_{n}\left(t_{n} \mid \mathbf{x}_{n}, \mathbf{z}_{n} ; \Theta\right)$.

\subsection{Identification}

In duration models, the failure to control for selectivity issues due to unobserved heterogeneity can lead to substantial biases in the estimation of the structural parameters of the hazard function. We control for the selection on unobservables on the basis of a discrete distribution with an unknown number of points of support, unknown probability masses, and unknown location of the points of support. Elbers and Ridder (1982) showed that under the MPH assumption, exogenous time-invariant regressor variation, and an auxiliary assumption on the first moment of the unobserved heterogeneity distribution, the model components are non-parametrically identified. If exogenous information from time-varying variables is available, like in this study, the MPH assumption is not necessary for identification and the impact of the covariates on the hazard function can be allowed to be heterogeneous over time (Brinch, 2007).

A further concern in credibly identifying the impact of offshoring on job stability is time-varying heterogeneity. There might indeed be other time-varying determinants of job stability which, if left out of the model specification, could give rise to spurious effects. In order to address this potential problem, we include in the model specification a rich set of time-varying variables at national, regional, and sectoral levels which might explain the job duration distribution. More in detail, we include: (i) time dummies to take into account idiosyncratic changes, like those determined by legislation changes; (ii) the regional unemployment rate to control for the state of the labour market; (iii) the sectoral ICT over output; (iv) the sectoral labour productivity which is a proxy for the efficiency and evolution in the sector; (v) the import penetration ratio which captures the competitive pressure from foreign firms in the same sector and may also reflect the general trade openness of the sector.

Finally, the combination of micro data about the duration of individual job spells and sectoral level indicators for offshoring helps in mitigating endogeneity concerns related to reverse causality. It is indeed unlikely that the individual behaviour is able to affect the sectoral performance in terms of foreign intermediate purchases.

\section{Estimation results}

Table 2 reports the estimation results of the job hazard function described in the previous section. The first two columns present the analysis for the sample of all employees. Consistently with our expectations, the sectoral purchases of foreign intermediate inputs significantly increase the worker's probability of experiencing a job separation. This positive effect on the job exit rate is robust to the definition of the offshoring measure (narrow or broad). ${ }^{12}$ Concerning the magnitude of the effect, we find

\footnotetext{
12 This finding contrasts with Geishecker (2008), who finds no support for a significant effect of the broadly defined offshoring.
}

that a 1 percentage points increase in the narrow (broad) offshoring increases the job exit rate by 3.4\% (3.2\%). Moreover, the purchases of KIBS abroad has a further negative effect on the job stability in manufacturing. ${ }^{13}$

Hence, the general process of fragmentation of production across countries seems to significantly affect the firm labour saving organization choices. The resulting higher dynamism in the labour market may generate important adjustment costs in terms of increased unemployment and need for workers' re-training. It might nonetheless represent an opportunity for the economic system to undergo structural changes that may improve and strengthen its competitiveness.

As mentioned above, in order to disentangle the true effect of offshoring from the spurious one determined by further time-varying heterogeneity, we included among the covariates a set of time-varying controls at sectoral and geographical level. The sectoral import penetration is aimed at controlling for the growing international integration among countries and the resulting stronger competitive pressures. We find that tougher international competition positively and significantly affects the job hazard rate. Thus, the general process of globalization seems to increase the job instability due both to the fragmentation strategies in which the domestic firms may engage and to the growing flows of foreign goods entering the domestic market. Another relevant phenomenon which may potentially affect the labour market dynamics is technological change. Contrary to some previous evidence (Geishecker, 2008), the advancements in technology, measured by the sectoral ICT capital stock, do not explain the job exit rate. According to expectations, the regional unemployment rate is positively related to the probability of job separation.

The estimated coefficients of the time-invariant covariates are broadly in line with those previously found for other industrialized countries. White collar workers and employees with Italian nationality have a significant lower probability of experiencing a job separation. Both the wage and previous working experience are positively associated with job durations. As in Munch (2010), older workers are less likely to exit the job. This contrasts with Geishecker (2008) who instead finds job stability decreasing with age, even if not linearly. Firm size matters and the larger the firm, the lower the job exit rate. Bigger firms might be less sensitive to the business cycle and shocks in the market. Differently from the results for other countries (Geishecker, 2008; Bachmann and Braun, 2011; Baumgarten, 2009), we find that men and women have the same job exit rate.

So far, we have considered offshoring to have a homogeneous impact on job stability regardless of the type of employees' tasks and activities. This is however a strong assumption since workers with a higher skill level and committed with knowledge and technology intensive tasks may be less substitutable by foreign inputs than workers performing simple and routinely jobs. The increasing international integration might affect more the low skilled

\footnotetext{
13 A 1 percentage points increase in KIBS increases the job hazard rate of about $62.0 \%-54.2 \%$, depending on the broad or narrow definition of material offshoring.
} 
Table 2

Estimation results of the systematic part of the job hazard function.

\begin{tabular}{|c|c|c|c|c|c|c|}
\hline & \multicolumn{2}{|c|}{ All employees } & \multicolumn{2}{|c|}{ White collars } & \multicolumn{2}{|l|}{ Blue collars } \\
\hline & $(1)$ & $(2)$ & (3) & $(4)$ & (5) & (6) \\
\hline \multirow[t]{2}{*}{ Constant } & $-1.941^{*}$ & $-2.844^{* *}$ & -2.768 & $-3.542^{*}$ & -0.769 & -1.544 \\
\hline & [1.120] & [1.106] & [2.024] & [1.908] & [1.395] & [1.397] \\
\hline \multirow[t]{2}{*}{ Female } & -0.017 & -0.017 & $-0.078^{* *}$ & $-0.079^{* *}$ & 0.011 & 0.011 \\
\hline & {$[0.020]$} & [0.020] & {$[0.040]$} & [0.040] & {$[0.024]$} & {$[0.024]$} \\
\hline \multirow[t]{2}{*}{ Age } & $-0.134^{* * *}$ & $-0.134^{* * *}$ & $-0.056^{* *}$ & $-0.055^{* *}$ & $-0.152^{* * *}$ & $-0.152^{* * *}$ \\
\hline & {$[0.011]$} & {$[0.011]$} & {$[0.026]$} & {$[0.026]$} & {$[0.012]$} & {$[0.012]$} \\
\hline \multirow[t]{2}{*}{ WhiteCollar } & $-0.195^{* * *}$ & $-0.195^{* * *}$ & & & & \\
\hline & {$[0.021]$} & {$[0.021]$} & & & & \\
\hline \multirow[t]{2}{*}{ Italian } & $-0.219^{* * *}$ & $-0.219^{* * *}$ & $-0.348^{* * *}$ & $-0.347^{* * *}$ & $-0.210^{* * *}$ & $-0.210^{* * *}$ \\
\hline & {$[0.044]$} & {$[0.044]$} & {$[0.128]$} & [0.129] & {$[0.047]$} & [0.047] \\
\hline \multirow[t]{2}{*}{ Wage } & $-0.080^{* * *}$ & $-0.080^{* * *}$ & $-0.083^{*}$ & $-0.085^{*}$ & $-0.108^{* * *}$ & $-0.107^{* * *}$ \\
\hline & {$[0.023]$} & [0.023] & {$[0.046]$} & {$[0.046]$} & {$[0.027]$} & [0.027] \\
\hline \multirow[t]{2}{*}{ WorkExp } & $-0.417^{* * *}$ & $-0.417^{* * *}$ & $-0.439^{* * *}$ & $-0.437^{* * *}$ & $-0.421^{* * *}$ & $-0.419^{* * *}$ \\
\hline & [0.051] & [0.051] & {$[0.092]$} & [0.093] & {$[0.061]$} & {$[0.061]$} \\
\hline \multirow[t]{2}{*}{ PrevJobs } & $-0.560^{* * *}$ & $-0.560^{* * *}$ & $-0.811^{*}$ & $-0.831^{*}$ & $-0.485^{* *}$ & $-0.489^{* *}$ \\
\hline & [0.207] & [0.207] & [0.428] & {$[0.430]$} & [0.238] & [0.239] \\
\hline \multirow[t]{2}{*}{ Quarter2 } & $0.199^{* * *}$ & $0.199^{* * *}$ & $0.197^{* * *}$ & $0.198^{* * *}$ & $0.196^{* * *}$ & $0.196^{* * *}$ \\
\hline & {$[0.021]$} & [0.021] & [0.046] & {$[0.046]$} & [0.023] & [0.023] \\
\hline \multirow[t]{2}{*}{ Quarter3 } & $0.320^{* * *}$ & $0.320^{* * *}$ & $0.366^{* * *}$ & $0.365^{* * *}$ & $0.304^{* * *}$ & $0.304^{* * *}$ \\
\hline & {$[0.023]$} & {$[0.023]$} & {$[0.052]$} & {$[0.052]$} & {$[0.026]$} & {$[0.026]$} \\
\hline \multirow[t]{2}{*}{ Quarter4 } & $0.281^{* * *}$ & $0.281^{* * * *}$ & $0.300^{* * *}$ & $0.298^{* * * *}$ & $0.275^{* * *}$ & $0.275^{* * * *}$ \\
\hline & [0.023] & [0.023] & [0.049] & [0.049] & {$[0.026]$} & {$[0.026]$} \\
\hline \multirow[t]{2}{*}{ Size2 } & $-0.088^{* * *}$ & $-0.088^{* * *}$ & $-0.140^{* *}$ & $-0.139^{* *}$ & $-0.071^{* * *}$ & $-0.072^{* * *}$ \\
\hline & {$[0.024]$} & {$[0.024]$} & [0.059] & [0.059] & {$[0.026]$} & {$[0.026]$} \\
\hline \multirow[t]{2}{*}{ Size3 } & $-0.096^{* * *}$ & $-0.096^{* * *}$ & $-0.127^{* *}$ & $-0.126^{* *}$ & $-0.087^{* * *}$ & $-0.087^{* * *}$ \\
\hline & {$[0.023]$} & [0.023] & [0.053] & [0.053] & {$[0.026]$} & {$[0.026]$} \\
\hline \multirow{2}{*}{ Size4 } & $-0.169^{* * *}$ & $-0.169^{* * *}$ & $-0.181^{* *}$ & $-0.180^{* *}$ & $-0.170^{* * *}$ & $-0.170^{* * *}$ \\
\hline & [0.038] & [0.038] & {$[0.072]$} & [0.072] & {$[0.046]$} & {$[0.046]$} \\
\hline \multirow[t]{2}{*}{ Size5 } & $-0.230^{* * *}$ & $-0.230^{* * *}$ & $-0.217^{* * *}$ & $-0.216^{* * *}$ & $-0.239^{* * *}$ & $-0.239^{* * *}$ \\
\hline & {$[0.025]$} & {$[0.025]$} & {$[0.055]$} & [0.055] & {$[0.028]$} & {$[0.028]$} \\
\hline Centre & 0.036 & 0.036 & $-0.100^{*}$ & $-0.101^{*}$ & $0.071^{* * *}$ & $0.071^{* * *}$ \\
\hline & {$[0.023]$} & [0.023] & {$[0.054]$} & {$[0.054]$} & {$[0.026]$} & {$[0.026]$} \\
\hline South & -0.02 & -0.021 & $-0.191^{*}$ & $-0.200^{*}$ & 0.014 & 0.014 \\
\hline & [0.046] & [0.046] & [0.110] & [0.110] & {$[0.051]$} & [0.051] \\
\hline$O F F_{K i b s}$ & $0.620^{* * *}$ & $0.542^{* * * *}$ & $0.691^{* * *}$ & $0.467^{* *}$ & $0.351^{* *}$ & $0.336^{* *}$ \\
\hline & [0.128] & [0.123] & [0.213] & [0.186] & [0.169] & [0.171] \\
\hline OFF $F_{\text {narrow }}$ & $0.034^{* * *}$ & & 0.015 & & $0.042^{* * *}$ & \\
\hline & [0.012] & & {$[0.022]$} & & {$[0.014]$} & \\
\hline OFF broad & & $0.032^{* * *}$ & & $0.050^{* * *}$ & & $0.023^{* *}$ \\
\hline & & [0.009] & & {$[0.016]$} & & [0.011] \\
\hline ImpPen $_{j}$ & $0.004^{* * *}$ & $0.004^{* * *}$ & $0.005^{* * *}$ & $0.004^{* *}$ & $0.003^{* * *}$ & $0.003^{* * *}$ \\
\hline & {$[0.001]$} & [0.001] & [0.002] & {$[0.002]$} & {$[0.001]$} & [0.001] \\
\hline Unemp ${ }^{\text {reg }}$ & $1.373^{* * *}$ & $1.375^{* * *}$ & $1.535^{* *}$ & $1.583^{* *}$ & $1.305^{* * *}$ & $1.310^{* * * *}$ \\
\hline & {$[0.336]$} & [0.336] & [0.760] & {$[0.761]$} & [0.375] & [0.376] \\
\hline$L P_{j}$ & -0.216 & -0.143 & -0.223 & -0.116 & -0.225 & -0.156 \\
\hline & [0.156] & [0.157] & [0.268] & {$[0.270]$} & [0.209] & [0.210] \\
\hline$I C T_{j}$ & 0.079 & 0.071 & 0.043 & 0.088 & 0.148 & 0.135 \\
\hline & {$[0.100]$} & [0.100] & [0.205] & [0.197] & [0.116] & [0.116] \\
\hline $\ln (v)$ & $-1.941^{*}$ & $-2.844^{* * *}$ & -2.768 & $-3.542^{*}$ & -0.769 & -1.544 \\
\hline & [1.045] & [1.030] & [1.979] & [1.831] & [1.295] & [1.302] \\
\hline$N T$ & 511,919 & 511,919 & 146,218 & 146,218 & 365,701 & 365,701 \\
\hline$N$ & 19,259 & 19,259 & 4,589 & 4,589 & 14,670 & 14,670 \\
\hline Log-likelihood & $-66,198.2$ & $-66,196.1$ & $-14,638.6$ & $-14,634.0$ & $-51,458.9$ & $-51,461.2$ \\
\hline
\end{tabular}

Standard errors are in brackets. Dummy indicators for years and sectors are included in all estimations but not reported for the sake of brevity. The reference employee is Italian, male, working in firms smaller than 20 employees in the sector of Furniture and other manufacturing industries, entering the sample in the first quarter of the year, and living in the North of Italy.

* Significant at $10 \%$ level.

** Significant at $5 \%$ level.

*** Significant at $1 \%$ level.

than the high skilled because of both their relative scarcity in advanced countries and the growing role of low skilled labour abundant countries in world trade flows. In particular, offshoring practices are often meant more to save on labour intensive fragments of production than to acquire new technologies from abroad (OECD, 2007).
In order to test whether offshoring differently affects the job security of workers according to their skills, we distinguish between blue and white collar workers. Columns (3)-(6) of Table 2 report the estimation results of our single risk model split by skill level. According to both measures of offshoring, the purchases of foreign inputs decrease the 
Table 3

The job baseline hazard profile of the estimated models.

\begin{tabular}{|c|c|c|c|c|c|c|}
\hline \multirow[t]{2}{*}{ Baseline coefficients } & \multicolumn{2}{|c|}{ All employees } & \multicolumn{2}{|c|}{ White collars } & \multicolumn{2}{|c|}{ Blue Collars } \\
\hline & $(1)$ & $(2)$ & $(3)$ & (4) & (5) & (6) \\
\hline \multirow[t]{2}{*}{$\alpha_{2}:[3,6)$ months } & $-0.359^{* * *}$ & $-0.359^{* * *}$ & $-0.286^{* * *}$ & $-0.287^{* * *}$ & $-0.369^{* * *}$ & $-0.369^{* * *}$ \\
\hline & {$[0.036]$} & {$[0.036]$} & {$[0.096]$} & {$[0.096]$} & {$[0.038]$} & {$[0.038]$} \\
\hline \multirow[t]{2}{*}{$\alpha_{3}:[6,9)$ months } & $-0.478^{* * *}$ & $-0.478^{* * *}$ & $-0.272^{* * *}$ & $-0.274^{* * *}$ & $-0.512^{* * *}$ & $-0.512^{* * *}$ \\
\hline & {$[0.038]$} & {$[0.038]$} & {$[0.097]$} & [0.097] & {$[0.042]$} & {$[0.042]$} \\
\hline \multirow[t]{2}{*}{$\alpha_{4}:[9,12)$ months } & $-0.062^{*}$ & $-0.063^{*}$ & $0.327^{* * *}$ & $0.325^{* * *}$ & $-0.141^{* * *}$ & $-0.141^{* * *}$ \\
\hline & {$[0.035]$} & {$[0.032]$} & {$[0.086]$} & {$[0.086]$} & {$[0.039]$} & {$[0.039]$} \\
\hline \multirow[t]{2}{*}{$\alpha_{5}:[12,18)$ months } & $-0.070^{* *}$ & $-0.070^{* *}$ & $0.224^{* * * *}$ & $0.221^{* * * *}$ & $-0.123^{* * *}$ & $-0.123^{* * * *}$ \\
\hline & {$[0.032]$} & {$[0.032]$} & {$[0.080]$} & {$[0.080]$} & {$[0.035]$} & {$[0.035]$} \\
\hline \multirow[t]{2}{*}{$\alpha_{6}:[18,24)$ months } & $0.101^{* * * *}$ & $0.101^{* * *}$ & $0.610^{* * *}$ & $0.608^{* * *}$ & -0.018 & -0.018 \\
\hline & [0.033] & {$[0.033]$} & {$[0.078]$} & {$[0.078]$} & {$[0.036]$} & {$[0.036]$} \\
\hline \multirow[t]{2}{*}{$\alpha_{7}:[24,30)$ months } & $-0.354^{* * *}$ & $-0.354^{* * *}$ & 0.068 & 0.066 & $-0.445^{* * *}$ & $-0.448^{* * * *}$ \\
\hline & [0.039] & [0.039] & {$[0.090]$} & {$[0.090]$} & {$[0.044]$} & {$[0.044]$} \\
\hline \multirow[t]{2}{*}{$\alpha_{8}:[30,36)$ months } & $-0.091^{* *}$ & $-0.092^{* *}$ & $0.263^{* * *}$ & $0.259^{* * *}$ & $-0.157^{* * *}$ & $-0.157^{* * *}$ \\
\hline & {$[0.038]$} & {$[0.038]$} & {$[0.090]$} & {$[0.090]$} & {$[0.043]$} & {$[0.043]$} \\
\hline \multirow[t]{2}{*}{$\alpha_{9}:[36,60)$ months } & $-0.140^{* * *}$ & $-0.140^{* * *}$ & $0.200^{* *}$ & $0.203^{* *}$ & $-0.199^{* * *}$ & -0.198 \\
\hline & {$[0.038]$} & {$[0.038]$} & [0.088] & [0.088] & {$[0.043]$} & {$[0.043]$} \\
\hline
\end{tabular}

Standard errors are in brackets. The baseline hazard is identified up to a constant, so $\alpha_{1}$ is normalized to 0 .

* Significant at $10 \%$ level.

** Significant at $5 \%$ level.

*** Significant at $1 \%$ level.

job stability of blue and white collar workers. ${ }^{14}$ Services purchased abroad significantly increase the job hazard function of both groups of workers and the magnitude of the effect is larger for white collars. This might be due to the fact that KIBS are characterized by very high knowledge requirements and need specific technical abilities. Hence, KIBS are usually performed by high skill workers and their delocalisation affects more the white collar workers' job stability. Even if we split the sample in white and blue collar workers, further heterogeneity might characterize the impact of offshoring on job stability. This is why in the next subsection, we control for another potential source of heterogeneity, that is the origin of the offshored intermediates.

Table 3 displays the profile of the baseline hazard of the models presented in Table 2. The job baseline hazards display non-monotonic profiles, with similar patterns for white and blue collar workers. The probability of job separation is decreasing in the first three quarters. It jumps up at the end of the first year and it is increasing until the end of the second year, when a spike is observed. Then, it bounces down in the first semester of the third year and, finally, it stabilizes from that moment onward. ${ }^{15}$ The decline of the job separation rate with tenure in the initial part of the job relationship and after the end of the second year is consistent with the central facts about working mobility (e.g. Topel and Ward, 1992; Farber, 1999). The spikes at the end of the first and second years of tenure might be related to the non-renewal of temporary contracts and to the dismissal of unproductive

\footnotetext{
14 The effect of narrow offshoring of white collar workers' job exit rate is, although positive, not significant at the $5 \%$ significance level.

15 In order to quantify the job baseline hazard in a given month for the reference individual, one has to take the exponential of the sum between the constant reported in Table 2 and the baseline coefficient of the corresponding month. Since the baseline hazard is identified up to a constant, $\alpha_{1}$ is normalized to 0 .
}

job matches. In a framework à la Jovanovic (1979) where the productivity of a particular worker-firm match is not observable ex-ante, but is revealed after a while, we might indeed observe spikes in the job separation rate. ${ }^{16}$

\subsection{The origin of imports}

Emerging and low labour cost countries have experienced a strong expansion during the last decades, both in terms of economic growth and trade flows in intermediates. Their increased role in the global economy has risen worries about the job stability of workers in advanced economies, even if most of the foreign inputs in high income countries are still imported from other developed partners.

There are different reasons why the impact of offshoring on job stability might depend on the origin country of the input flows. As mentioned above, imports from low labour cost countries are likely to hide cost saving reasons, whereas imports from high income economies may stem from the search for a better technology. Moreover, the skill intensity of the two types of imports is found to be different, thus implying a heterogeneous impact on workers according to their skill level (Fitzgerald and Hallak, 2004; Schott, 2003). Aware of this, we take into account the importance of the country where the production is offshored to and, especially, we cross heterogeneous import origins with the different occupation skills. We expect offshoring to low income countries to play the major role on the recent labour market evolution, due to its recent growth in magnitude and to its general labour saving purpose. In what follows, we only display the results for our offshoring measures

\footnotetext{
16 Cockx and abd Picchio (2012) report similar spikes in the job separation rates at the end of the first year of tenure for young workers in Belgium.
} 
Table 4

Estimation results of offshoring by skill level and origin countries.

\begin{tabular}{|c|c|c|c|c|c|c|}
\hline & \multicolumn{2}{|c|}{ All employees } & \multicolumn{2}{|c|}{ White collars } & \multicolumn{2}{|l|}{ Blue collars } \\
\hline & $(1)$ & $(2)$ & (3) & $(4)$ & (5) & (6) \\
\hline OFF $F_{\text {Kibs }}$ & $\begin{array}{l}0.628^{* * *} \\
{[0.129]}\end{array}$ & $\begin{array}{l}0.548^{* * *} \\
{[0.124]}\end{array}$ & $\begin{array}{l}0.688^{* * *} \\
{[0.212]}\end{array}$ & $\begin{array}{l}0.472^{* *} \\
{[0.184]}\end{array}$ & $\begin{array}{l}0.362^{* *} \\
{[0.171]}\end{array}$ & $\begin{array}{l}0.351^{* *} \\
{[0.176]}\end{array}$ \\
\hline OFF & $\begin{array}{l}0.024^{*} \\
{[0.013]}\end{array}$ & & $\begin{array}{l}0.023 \\
{[0.024]}\end{array}$ & & $\begin{array}{l}0.024 \\
{[0.016]}\end{array}$ & \\
\hline$O F F_{\text {narrow }}^{\text {Low }}$ & $\begin{array}{l}0.079^{* * *} \\
{[0.030]}\end{array}$ & & $\begin{array}{c}-0.034 \\
{[0.078]}\end{array}$ & & $\begin{array}{l}0.109^{* * *} \\
{[0.033]}\end{array}$ & \\
\hline OFF $F_{\text {broad }}^{\text {High }}$ & & $\begin{array}{l}0.024^{* *} \\
{[0.011]}\end{array}$ & & $\begin{array}{l}0.061^{* * *} \\
{[0.018]}\end{array}$ & & $\begin{array}{l}-0.002 \\
{[0.014]}\end{array}$ \\
\hline OFF broad & & $\begin{array}{l}0.070^{* *} \\
{[0.029]}\end{array}$ & & $\begin{array}{c}-0.048 \\
{[0.076]}\end{array}$ & & $\begin{array}{l}0.110^{* * *} \\
{[0.031]}\end{array}$ \\
\hline $\operatorname{ImpPen}_{j}$ & $\begin{array}{l}0.004^{* * *} \\
{[0.001]}\end{array}$ & $\begin{array}{l}0.004^{* * *} \\
{[0.001]}\end{array}$ & $\begin{array}{l}0.005^{* * *} \\
{[0.002]}\end{array}$ & $\begin{array}{l}0.004^{* *} \\
{[0.002]}\end{array}$ & $\begin{array}{l}0.003^{* * *} \\
{[0.001]}\end{array}$ & $\begin{array}{l}0.003^{* * *} \\
{[0.001]}\end{array}$ \\
\hline Unemp ${ }^{\text {reg }}$ & $\begin{array}{l}1.373^{* * *} \\
{[0.336]}\end{array}$ & $\begin{array}{l}1.375^{* * *} \\
{[0.336]}\end{array}$ & $\begin{array}{l}1.537^{* *} \\
{[0.760]}\end{array}$ & $\begin{array}{l}1.582^{* *} \\
{[0.761]}\end{array}$ & $\begin{array}{l}1.306^{* * *} \\
{[0.375]}\end{array}$ & $\begin{array}{l}1.314^{* * *} \\
{[0.375]}\end{array}$ \\
\hline$L P_{j}$ & $\begin{array}{l}-0.2 \\
{[0.156]}\end{array}$ & $\begin{array}{c}-0.126 \\
{[0.157]}\end{array}$ & $\begin{array}{c}-0.237 \\
{[0.267]}\end{array}$ & $\begin{array}{c}-0.134 \\
{[0.270]}\end{array}$ & $\begin{array}{l}-0.201 \\
{[0.209]}\end{array}$ & $\begin{array}{l}-0.101 \\
{[0.210]}\end{array}$ \\
\hline$I C T_{j}$ & $\begin{array}{l}0.049 \\
{[0.102]}\end{array}$ & $\begin{array}{l}0.053 \\
{[0.101]}\end{array}$ & $\begin{array}{l}0.071 \\
{[0.210]}\end{array}$ & $\begin{array}{l}0.123 \\
{[0.198]}\end{array}$ & $\begin{array}{l}0.105 \\
{[0.118]}\end{array}$ & $\begin{array}{l}0.088 \\
{[0.118]}\end{array}$ \\
\hline$N T$ & 511,919 & 511,919 & 146,218 & 146,218 & 365,701 & 365,701 \\
\hline$N$ & 19,259 & 19,259 & 4,589 & 4,589 & 14,670 & 14,670 \\
\hline Log-likelihood & $-66,197.1$ & $-66,195.3$ & $-14,638.4$ & $-14,633.1$ & $-51,456.8$ & $-51,457.3$ \\
\hline
\end{tabular}

Standard errors are in brackets.

* Significant at $10 \%$ level.

** Significant at $5 \%$ level.

*** Significant at $1 \%$ level.

and other sectoral and regional variables for the sake of brevity. ${ }^{17}$

Using both the broad and the narrow measures of offshoring, Table 4 shows that, focusing on the sample of all workers, among the measures of material imports the main negative impact for the job stability is displayed for the process of production fragmentation to developing countries. As a matter of fact, although the impact of input purchases from high income countries on the job hazard rate is positive, the coefficient is smaller and the significance level is lower. Offshoring of KIBS still contributes to reduce the probability of workers to preserve their jobs.

The most interesting insights, however, are delivered when we take simultaneously into account the two heterogeneity sources, worker skills and origin of inputs. Material offshoring to low income countries represents a detrimental factor of the job stability only of blue collar workers. A 1 percentage points increase in the narrow or broad offshoring share increases the monthly job exit rate of blue collar workers by about $11 \%$. This is in line with previous empirical evidence and also supported by Lo Turco and Maggioni (2012), who find that in Italy offshoring affects the firm labour demand only if it is towards low income countries. ${ }^{18}$ In contrast, material offshoring to high income countries increases the probability

\footnotetext{
17 The full set of estimation results are available from the authors upon request.

18 The negative effect of offshoring to developing countries on the firm labour demand displayed in Lo Turco and Maggioni (2012) is especially important in traditional sectors, defined as the ones belonging to the group "Supplier-Dominated" sectors according to Pavitt's taxonomy, where the share of low skilled workers is usually higher.
}

of white collars of experiencing a job separation only when computed according to the broad definition. If purchases from advanced economies consist of more knowledge intensive goods, then they may well substitute for white collars, especially in the case of material imports not directly related to the core business of the firm. As a matter of fact, taking a vehicle manufacturer as an example, imports of computers may substitute for the work of some of the firm administrative employees, as well as importing advanced technology electronic devices may turn engineers and designers redundant. Both imports are not included in the narrow definition of offshoring, but they belong to the broad one.

\subsection{Assessing the magnitude of the offshoring effect}

To have a better understanding of the magnitude of the effect of offshoring on the job exit rate, we predict job survivor functions under three different counterfactual scenarios and compare them to the job survivor function predicted using the actual data. The three counterfactual scenarios are characterized by different levels of offshoring: (i) we increase the actual level by one standard deviation; (ii) we set it to the maximum value recorded in the period under analysis; (iii) we set it to zero. When we set the counterfactual offshoring to the maximum value, we mimic what the job exit rate would be if there were an economic wide movement towards the sector with the largest offshoring. When we set offshoring to zero, we instead predict the job exit rate in a sort of autarchic economic system.

We run this exercise on the basis of the estimation results presented in Table 4 with the broad definition of 
(a) All employees

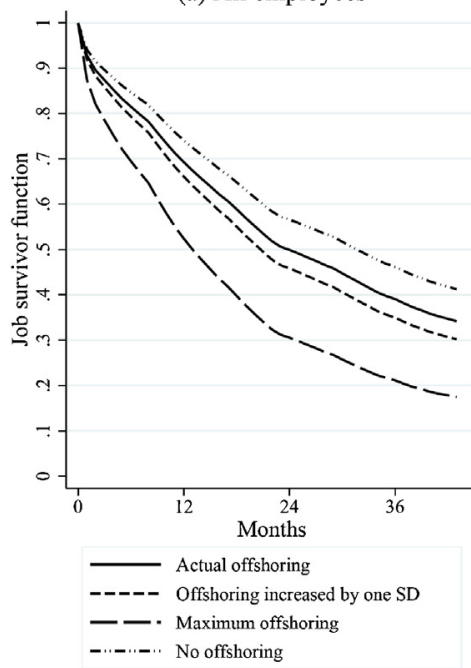

(b) White collar workers

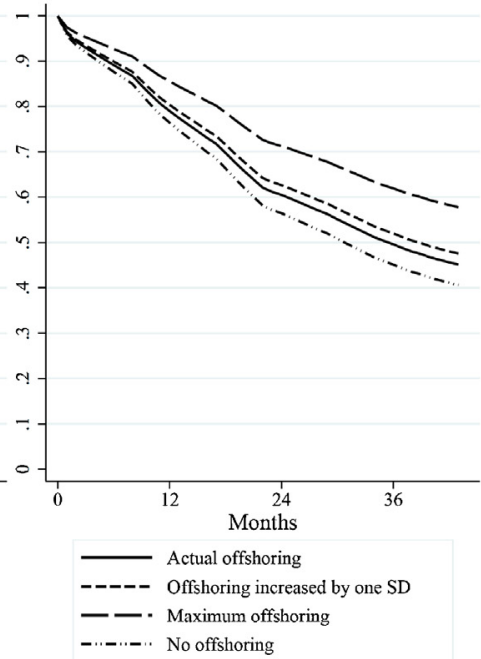

(c) Blue collar workers

Fig. 2. Predicted job survivor functions under different scenarios of material offshoring to low income countries.

(a) All employees

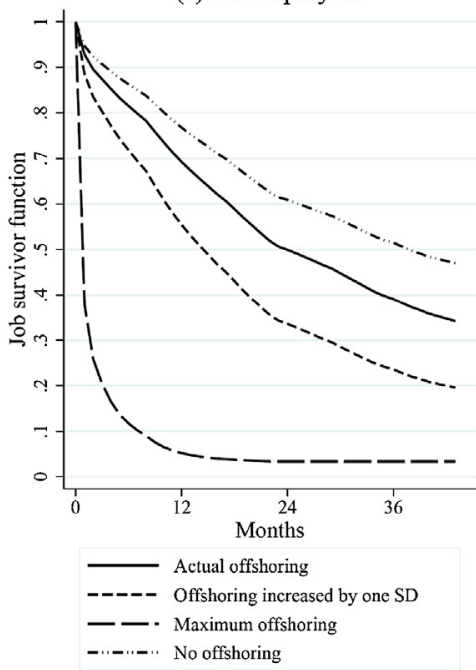

(b) White collar workers

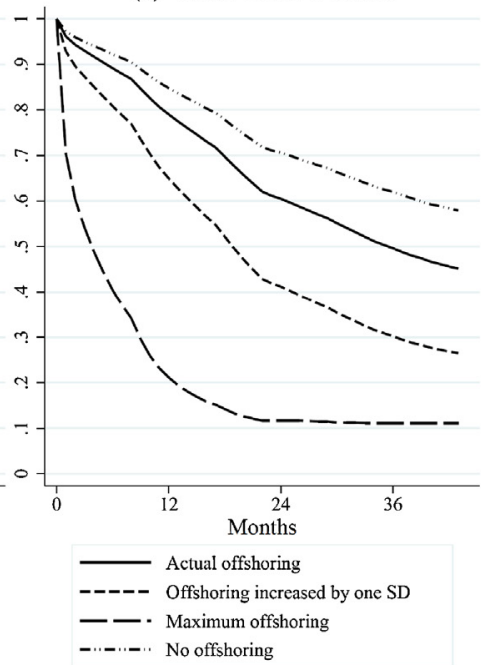

(c) Blue collar workers

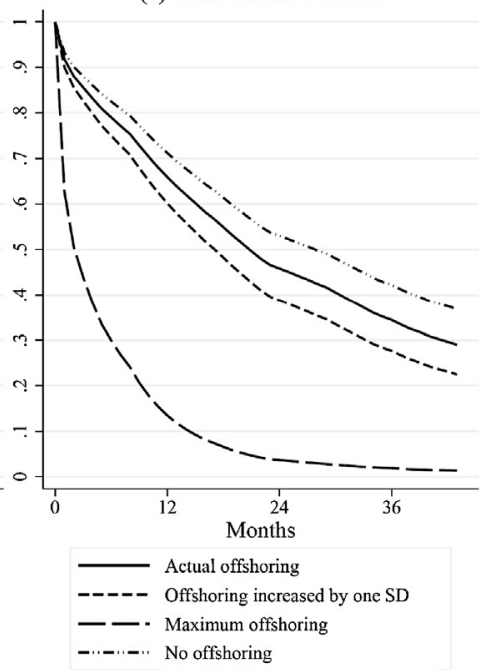

Fig. 3. Predicted job survivor functions under different scenarios of service offshoring.

material offshoring. We replicate it twice: first, we fix service offshoring $\left(O F F_{K i b s}\right)$ at the level observed in the actual data and we let broad material offshoring to low income countries $\left(O F F_{\text {broad }}^{\text {Low }}\right.$ ) vary according to different scenarios; second, we let service offshoring vary while material offshoring to low income countries is fixed at the actual value. Since the material offshoring effect looks stronger for blue collar workers and when the origin countries are low income, we decide to focus on $O F F_{\text {broad }}^{\text {Low }}$, while always keeping the material offshoring to high income countries $\left(O F F_{\text {broad }}^{\text {High }}\right)$ fixed at the level observed in the data.

Fig. 2 reports the predicted job survivor functions under the different scenarios described above for material offshoring to low income countries, for all the employees (graph (a)), for white collar workers (graph (b)), and for blue collar workers (graph (c)). Fig. 2 suggests that material offshoring to low income countries has a sizable impact on the job survivor probability. If material offshoring to low income countries increases by one standard deviation, the probability that a job match lasts more than 2 years decreases from $49.9 \%$ to $45.8 \%$. This effect is totally driven by blue collar workers. When we limit the sample to blue collar workers, the effect is indeed larger in relative and absolute size, moving from $45.8 \%$ to $38.8 \%$. If there were an economy wide movement to the sector with the highest offshoring to low income countries, blue collar workers' probability of surviving in a job for 24 months would decrease to $16.4 \%{ }^{19}$ Fig. 2 suggests therefore that material offshoring to low income economies importantly affects the exit rate from a manufacturing job.

\footnotetext{
19 We get similar figures if we run this analysis by playing with $O F F_{\text {narrow }}^{\text {Low }}$ instead of $O F F_{\text {broad }}^{\text {Low }}$
} 
Fig. 3 focuses, instead, on the predicted job survivor functions under the different scenarios for service offshoring. Like material offshoring, service offshoring has a sizable impact on the job survivor function. It is worth mentioning that, differently from material offshoring to low income countries, blue collar workers are less affected by service offshoring than white collar workers. If service offshoring increases by one standard deviation, the probability that a job relationship lasts more than 2 years decreases from $59.7 \%$ to $40.2 \%$ for white collar workers and from $45.8 \%$ to $38.8 \%$ for blue collar workers. It seems, therefore, that purchases of services from abroad present a lower degree of substitutability with blue collar workers.

\subsection{Competing risks}

So far, we have studied the job stability in a single risk framework, without distinguishing between different destinations in case of job separation. In what follows, we re-estimate the duration model in a competing risks framework with two risks of job exit: transition to another job in the manufacturing sector and transition out of the manufacturing sector. Like in the single risk framework, we estimated competing risks models encompassing unobserved heterogeneity with a discrete distribution. More in detail, we specified a bivariate discrete distribution of the unobserved determinants of each transition intensity with free correlation matrix. However, as in the single risk case, we were never able to improve the likelihood with respect to the model without unobserved heterogeneity. The procedure we used to move from the model without unobserved heterogeneity to the model with unobserved heterogeneity is the same as the one for single risk models described in Section 4.1. We decide to focus on job-tojob transitions within manufacturing and on transitions out of manufacturing since the welfare consequences of these transitions may be very different. Transitions out of manufacturing employment have immediate detrimental effects for the economy in terms of deterioration of sectoral specific human capital and, thereby, higher risk of future unemployment, skill obsolescence, and costs related to re-training programmes. Instead, job-to-job transitions within manufacturing might not represent a real damage, as they might put an end to bad job matches and move employees towards more technology and knowledge intensive firms, which are also less exposed to international competition.

Table 5 displays the estimation results of the competing risks proportional hazard model with the indicator of offshoring split by country groups. The upper and bottom panels display the effects for out of manufacturing transitions and job-to-job transitions, respectively. The input purchases from low income countries only significantly increase the transitions out of manufacturing for the total sample of employees. Offshoring to developed countries displays instead no role. However, when we separately consider white and blue collar workers, the detrimental effect of offshoring to low income countries on the job stability only concerns blue collar workers. A 1 percentage point increase in the narrow (broad) offshoring share increases blue collars' job exit rate out of manufacturing by
$18.9 \%(17.3 \%)$. Thus, consistently with our expectations, the process of delocalisation of production towards developing countries throws only blue collars out of manufacturing sector.

Offshoring to developing countries has no effect on jobto-job transitions either for white collars or for blue collars. Only a mild and barely significant impact is found for blue collar workers when the broad measure is used.

Moving on offshoring to high income countries, we find a positive and significant effect on the white collars' probability of experiencing a job change. Consistently with the evidence displayed by the single risk model, this role is detected only by the broad measure of offshoring.

The flows of KIBS from abroad do not contribute to the workers' exits from manufacturing sector. They instead affect the job-to-job transitions of all workers, even if, as in the single risk model, a higher magnitude of their impact is recorded for white collars' transitions. Thus, the process of delocalisation of services seems to contribute to the structural change in the economic system, since it drives workers away from the sectors more exposed to foreign pressures and, possibly, towards higher technology and more knowledge intensive sectors.

Finally, the results concerning the other sectoral and regional variables show that the sectoral import penetration seems to lead to job-to-job transitions and to drive blue collars only out of manufacturing. Therefore blue collar workers are more exposed to the growing international integration across countries. Also, regional unemployment, as expected, increases the probability of workers, regardless of their skill level, to exit the manufacturing sector.

Summing up, the overall analysis shows that it is mainly the purchase of inputs from low labour cost economies to increase the job separations. This effect is however restricted to low skilled workers. Therefore, while blue collars are driven out of manufacturing by the firm delocalisation process to developing countries, white collars experience transitions to another manufacturing job following the expansion of offshoring to high income countries. Thus, the main focus of policy intervention should be on low skilled workers, who are those mostly affected by the process of fragmentation of production across countries and, more in general, by the deeper and deeper integration of countries, as also shown by the indicator of import penetration.

\subsection{Further sensitivity checks}

We ran some sensitivity checks to test the robustness of the estimations results presented above. First, we relaxed the imposed proportionality of offshoring variables and tested whether freshly hired workers are differently affected by an increase in offshoring activities than workers with higher job seniority. We find that the offshoring effect displays some heterogeneity according to workers' tenure. The negative impact of offshoring on job stability is stronger for workers who have been working for more than one year if we use the broad measure of offshoring. When we use the narrow indicator, we get homogeneous effects over the job tenure. 
Table 5

Estimation results of the competing risks models.

\begin{tabular}{|c|c|c|c|c|c|c|}
\hline & \multicolumn{2}{|c|}{ All employees } & \multicolumn{2}{|c|}{ White collars } & \multicolumn{2}{|l|}{ Blue collars } \\
\hline & $(1)$ & $(2)$ & (3) & $(4)$ & $(5)$ & (6) \\
\hline \multicolumn{7}{|c|}{ Out of manufacturing } \\
\hline OFF & $\begin{array}{l}0.439^{*} \\
{[0.257]}\end{array}$ & $\begin{array}{l}0.395 \\
{[0.271]}\end{array}$ & $\begin{array}{l}0.559 \\
{[0.417]}\end{array}$ & $\begin{array}{l}0.449 \\
{[0.456]}\end{array}$ & $\begin{array}{l}-0.127 \\
{[0.362]}\end{array}$ & $\begin{array}{l}-0.154 \\
{[0.368]}\end{array}$ \\
\hline OFF $F_{\text {narrow }}^{\text {High }}$ & $\begin{array}{l}-0.007 \\
{[0.024]}\end{array}$ & & $\begin{array}{l}-0.033 \\
{[0.049]}\end{array}$ & & $\begin{array}{l}0.016 \\
{[0.028]}\end{array}$ & \\
\hline OFF & $\begin{array}{l}0.167^{* * *} \\
{[0.053]}\end{array}$ & & $\begin{array}{l}0.074 \\
{[0.143]}\end{array}$ & & $\begin{array}{l}0.189^{* * *} \\
{[0.058]}\end{array}$ & \\
\hline OFF $F_{\text {broad }}^{\text {High }}$ & & $\begin{array}{l}-0.010 \\
{[0.018]}\end{array}$ & & $\begin{array}{l}-0.002 \\
{[0.031]}\end{array}$ & & $\begin{array}{l}-0.015 \\
{[0.025]}\end{array}$ \\
\hline OFF $F_{\text {broad }}^{\text {Low }}$ & & $\begin{array}{l}0.159^{* * *} \\
{[0.051]}\end{array}$ & & $\begin{array}{l}0.110 \\
{[0.136]}\end{array}$ & & $\begin{array}{l}0.173^{* * *} \\
{[0.056]}\end{array}$ \\
\hline $\operatorname{ImpPen}_{j}$ & $\begin{array}{l}0.004^{* *} \\
{[0.002]}\end{array}$ & $\begin{array}{l}0.004^{* *} \\
{[0.002]}\end{array}$ & $\begin{array}{l}0.004 \\
{[0.004]}\end{array}$ & $\begin{array}{l}0.004 \\
{[0.004]}\end{array}$ & $\begin{array}{l}0.004^{*} \\
{[0.002]}\end{array}$ & $\begin{array}{l}0.004^{*} \\
{[0.002]}\end{array}$ \\
\hline Unemp ${ }^{\text {reg }}$ & $\begin{array}{l}3.876^{* * *} \\
{[0.655]}\end{array}$ & $\begin{array}{l}3.902^{* * *} \\
{[0.656]}\end{array}$ & $\begin{array}{l}5.731^{* * *} \\
{[1.418]}\end{array}$ & $\begin{array}{l}5.779^{* * *} \\
{[1.419]}\end{array}$ & $\begin{array}{l}3.373^{* * *} \\
{[0.750]}\end{array}$ & $\begin{array}{l}3.389^{* * *} \\
{[0.749]}\end{array}$ \\
\hline$L P_{j}$ & $\begin{array}{l}1.486 \\
{[4.009]}\end{array}$ & $\begin{array}{l}1.366 \\
{[3.932]}\end{array}$ & $\begin{array}{l}5.616 \\
{[6.890]}\end{array}$ & $\begin{array}{l}5.413 \\
{[6.599]}\end{array}$ & $\begin{array}{l}-1.216 \\
{[5.131]}\end{array}$ & $\begin{array}{l}-0.951 \\
{[5.089]}\end{array}$ \\
\hline$I C T_{j}$ & $\begin{array}{l}1.344 \\
{[1.826]}\end{array}$ & $\begin{array}{l}1.590 \\
{[1.805]}\end{array}$ & $\begin{array}{l}4.710 \\
{[3.222]}\end{array}$ & $\begin{array}{l}5.402^{*} \\
{[3.101]}\end{array}$ & $\begin{array}{l}1.211 \\
{[2.319]}\end{array}$ & $\begin{array}{l}1.345 \\
{[2.311]}\end{array}$ \\
\hline \multicolumn{7}{|c|}{ Job to job within manufacturing } \\
\hline$O F F_{K i b s}$ & $\begin{array}{l}0.705^{* * *} \\
{[0.175]}\end{array}$ & $\begin{array}{l}0.646^{* * *} \\
{[0.180]}\end{array}$ & $\begin{array}{l}0.774^{* * *} \\
{[0.288]}\end{array}$ & $\begin{array}{l}0.503^{*} \\
{[0.304]}\end{array}$ & $\begin{array}{l}0.492^{* *} \\
{[0.224]}\end{array}$ & $\begin{array}{l}0.465^{* *} \\
{[0.228]}\end{array}$ \\
\hline OFF $F_{\text {narrow }}^{\text {High }}$ & $\begin{array}{l}0.039^{*} \\
{[0.020]}\end{array}$ & & $\begin{array}{l}0.057 \\
{[0.039]}\end{array}$ & & $\begin{array}{l}0.023 \\
{[0.024]}\end{array}$ & \\
\hline OFF $F_{\text {narrow }}^{\text {Low }}$ & $\begin{array}{l}0.043 \\
{[0.047]}\end{array}$ & & $\begin{array}{c}-0.081 \\
{[0.126]}\end{array}$ & & $\begin{array}{l}0.068 \\
{[0.051]}\end{array}$ & \\
\hline$O F F_{\text {broad }}^{\text {High }}$ & & $\begin{array}{l}0.036^{* *} \\
{[0.014]}\end{array}$ & & $\begin{array}{l}0.103^{* * *} \\
{[0.026]}\end{array}$ & & $\begin{array}{l}0.002 \\
{[0.019]}\end{array}$ \\
\hline OFF $F_{\text {broad }}^{\text {Low }}$ & & $\begin{array}{l}0.037 \\
{[0.042]}\end{array}$ & & $\begin{array}{l}-0.128 \\
{[0.113]}\end{array}$ & & $\begin{array}{l}0.082^{*} \\
{[0.046]}\end{array}$ \\
\hline $\mathrm{ImpPen}_{j}$ & $\begin{array}{l}0.003^{* * *} \\
{[0.001]}\end{array}$ & $\begin{array}{l}0.003^{* * *} \\
{[0.001]}\end{array}$ & $\begin{array}{l}0.003 \\
{[0.002]}\end{array}$ & $\begin{array}{l}0.002 \\
{[0.002]}\end{array}$ & $\begin{array}{l}0.003^{* *} \\
{[0.001]}\end{array}$ & $\begin{array}{l}0.003^{* * *} \\
{[0.001]}\end{array}$ \\
\hline Unemp ${ }^{\text {reg }}$ & $\begin{array}{l}0.413 \\
{[0.410]}\end{array}$ & $\begin{array}{l}0.415 \\
{[0.410]}\end{array}$ & $\begin{array}{l}-0.459 \\
{[1.009]}\end{array}$ & $\begin{array}{l}-0.400 \\
{[1.006]}\end{array}$ & $\begin{array}{l}0.564 \\
{[0.454]}\end{array}$ & $\begin{array}{l}0.575 \\
{[0.454]}\end{array}$ \\
\hline$L P_{j}$ & $\begin{array}{l}-3.682 \\
{[2.812]}\end{array}$ & $\begin{array}{l}-3.852 \\
{[2.780]}\end{array}$ & $\begin{array}{l}-7.987 \\
{[5.727]}\end{array}$ & $\begin{array}{l}-6.577 \\
{[5.516]}\end{array}$ & $\begin{array}{l}-1.501 \\
{[3.262]}\end{array}$ & $\begin{array}{l}-1.488 \\
{[3.255]}\end{array}$ \\
\hline$I C T_{j}$ & $\begin{array}{l}0.363 \\
{[1.344]}\end{array}$ & $\begin{array}{l}0.612 \\
{[1.321]}\end{array}$ & $\begin{array}{l}-2.224 \\
{[2.812]}\end{array}$ & $\begin{array}{l}-1.421 \\
{[2.722]}\end{array}$ & $\begin{array}{l}1.536 \\
{[1.559]}\end{array}$ & $\begin{array}{l}1.626 \\
{[1.543]}\end{array}$ \\
\hline$N T$ & 511,919 & 511,919 & 146,218 & 146,218 & 365,701 & 365,701 \\
\hline$N$ & 19,259 & 19,259 & 4,589 & 4,589 & 14,670 & 14,670 \\
\hline Log-likelihood & $-74,435.8$ & $-74,433.8$ & $-16,395.6$ & $-16,387.8$ & $-57,898.4$ & -57899.4 \\
\hline
\end{tabular}

Second, we tested whether heterogeneous effects could be detected on differently aged workers. Differently from Bachmann and Braun (2011), we find no such evidence.

Third, we substituted output for non energy intermediates in the denominator of our offshoring measures and all the estimation results of interest are very much in line with those presented above. ${ }^{20}$ The full set of estimation results

\footnotetext{
20 The need for this check stems from the fact that, if in a sector some intermediate production is outsourced to domestic suppliers, the offshoring indicator normalized on sectoral intermediates will decrease because of the increased purchases of domestic intermediate inputs, on the contrary the offshoring indicator normalized on sectoral output will not experience any change. The confirmation of our results by making use of the latter indicator, then, lets us confident that our findings about the impact on workers' job stability are actually driven by the offshoring phenomenon and are not related to the process of domestic outsourcing.
}

of these sensitivity checks are not reported for the sake of brevity, but are available in the Web Appendix.

Finally, we re-estimated the model assuming that the monthly probability of job separation has a logit form. In a logit framework, it is, indeed, easy to allow the unobserved heterogeneity components to be arbitrarily related to the set of covariates. We can therefore relax the random effects assumption of a standard hazard function approach. Table 6 reports the estimation results of the variables of primary interest of a fixed effects logit model for the monthly rate of job separation. Qualitatively, we obtain the same findings as in the benchmark model (Table 2). Since in a fixed effects logit model it is not possible to quantify the impact of covariates and the parameters depend on the time unit of observation (Flinn and Heckman, 1982), we prefer to stick 
Table 6

Fixed effects logit estimation results.

\begin{tabular}{|c|c|c|c|c|c|c|}
\hline & \multicolumn{2}{|c|}{ All employees } & \multicolumn{2}{|c|}{ White collars } & \multicolumn{2}{|l|}{ Blue collars } \\
\hline & (1) & $(2)$ & (3) & (4) & (5) & (6) \\
\hline$O F F_{K i b s}$ & $\begin{array}{l}39.598^{* * *} \\
{[1.392]}\end{array}$ & $\begin{array}{l}39.289^{* * *} \\
{[1.309]}\end{array}$ & $\begin{array}{l}26.469^{* * *} \\
{[2.003]}\end{array}$ & $\begin{array}{l}26.753^{* * *} \\
{[2.020]}\end{array}$ & $\begin{array}{l}55.596^{* * *} \\
{[2.003]}\end{array}$ & $\begin{array}{l}55.330^{* * *} \\
{[1.931]}\end{array}$ \\
\hline OFF narrow & $\begin{array}{l}0.948^{* * *} \\
{[0.063]}\end{array}$ & & $\begin{array}{l}0.909^{* * *} \\
{[0.124]}\end{array}$ & & $\begin{array}{l}1.122^{* * *} \\
{[0.087]}\end{array}$ & \\
\hline OFF broad & & $\begin{array}{l}0.432^{* * *} \\
{[0.043]}\end{array}$ & & $\begin{array}{l}0.116^{* * *} \\
{[0.069]}\end{array}$ & & $\begin{array}{l}0.713^{* * *} \\
{[0.060]}\end{array}$ \\
\hline$N T$ & 299,175 & 299,175 & 71,307 & 71,307 & 227,868 & 227,868 \\
\hline$N$ & 14,554 & 14,554 & 3,125 & 3,125 & 11,429 & 11,429 \\
\hline Log-likelihood & $-27,442.1$ & $-27,530.4$ & $-6,121.2$ & $-6,153.8$ & $-21,091.9$ & $-21,124.6$ \\
\hline
\end{tabular}

*Significant at $10 \%$ level.

${ }^{* *}$ Significant at $5 \%$ level.

*** Significant at $1 \%$ level.

Standard errors are in brackets. The time-varying variables included in the benchmark hazard function models are also included in the fixed effects logit models but not reported for the sake of brevity. The number of observations is lower since individual for whom the outcome variable is always 0 or 10 (right censored observations) do not contribute to the likelihood function in a fixed effects logit approach.

to the hazard function specification of the benchmark model.

\section{Conclusions}

The consequences of offshoring activities in advanced countries depend on the time horizon. The theoretical possibility of increased job exit rates from offshoring in the short run is offset by the long run productivity gains accruing to all the workers involved in manufacturing production. Nevertheless, it may well take a long time before the firm may reap the gains from increased specialization and succeed in increasing its competitiveness. Meanwhile, the adjustment process may produce long-lasting economic and social costs. Regardless of the potential long run benefits of delocalisation, the short run consequences of offshoring are a relevant issue from the policy viewpoint, since any policy intervention should be firstly concerned with restraining the immediate welfare costs and with easing the transition to a new equilibrium. For this reason, the focus of our work is on the impact of offshoring on employees' job stability.

In the empirical analysis, we estimated MPH duration models to understand the impact of offshoring on the job hazard function. Our findings suggest that the process of international fragmentation of production significantly reduces the job stability in the Italian manufacturing sector. The effect of offshoring is however heterogeneous across skill groups and depends on the origin country of inputs. As a matter of fact, imports of intermediates from low labour cost countries appear to significantly and more strongly reduce the job stability of workers and the magnitude of this effect is quite large. Offshoring to developed countries, instead, increases the white collars' probability of experiencing a within manufacturing job-to-job transition and offshoring of KIBS favours all the workers' transition to another manufacturing job, the input flows from low income economies push blue collar workers out of manufacturing. Blue collar workers are therefore affected most by offshoring. We provide moreover evidence that the competitive pressure from foreign countries on the domestic markets, measured by the sectoral import penetration, increases the probability of unskilled workers to exit the manufacturing sector. This suggests that the international integration process, captured by both the expansion in offshoring activities and the increased import penetration, is driving the dismantling of manufacturing activities, at least of those activities characterized by less knowledge/technology intensity and by more routinely tasks.

As a consequence, policy makers should especially devote their attention to low skilled workers and should ease their re-training and their skill upgrading, in order to foster their transition to more knowledge intensive jobs, which are less affected by the international competition.

\section{Acknowledgments}

Alessia Lo Turco acknowledges financial support by MIUR through the 2009 Research Project of National Relevance (PRIN) on Structural Change led by Neri Salvadori. Matteo Picchio acknowledges financial support by the Research Foundation - Flanders (FWO), Belgium, during the period at Sherppa and the Department of Social Economics of Ghent University, from October 2011 until October 2012. We wish to thank Rosario Crinò and Lucia Tajoli for their useful comments and suggestions. We are also grateful to the participants to the X Brucchi Luchino Labour Economics Workshop (Rome, December 2011) and the Italian Trade Study Group Workshop (Rome, February 2012). 
Appendix A.
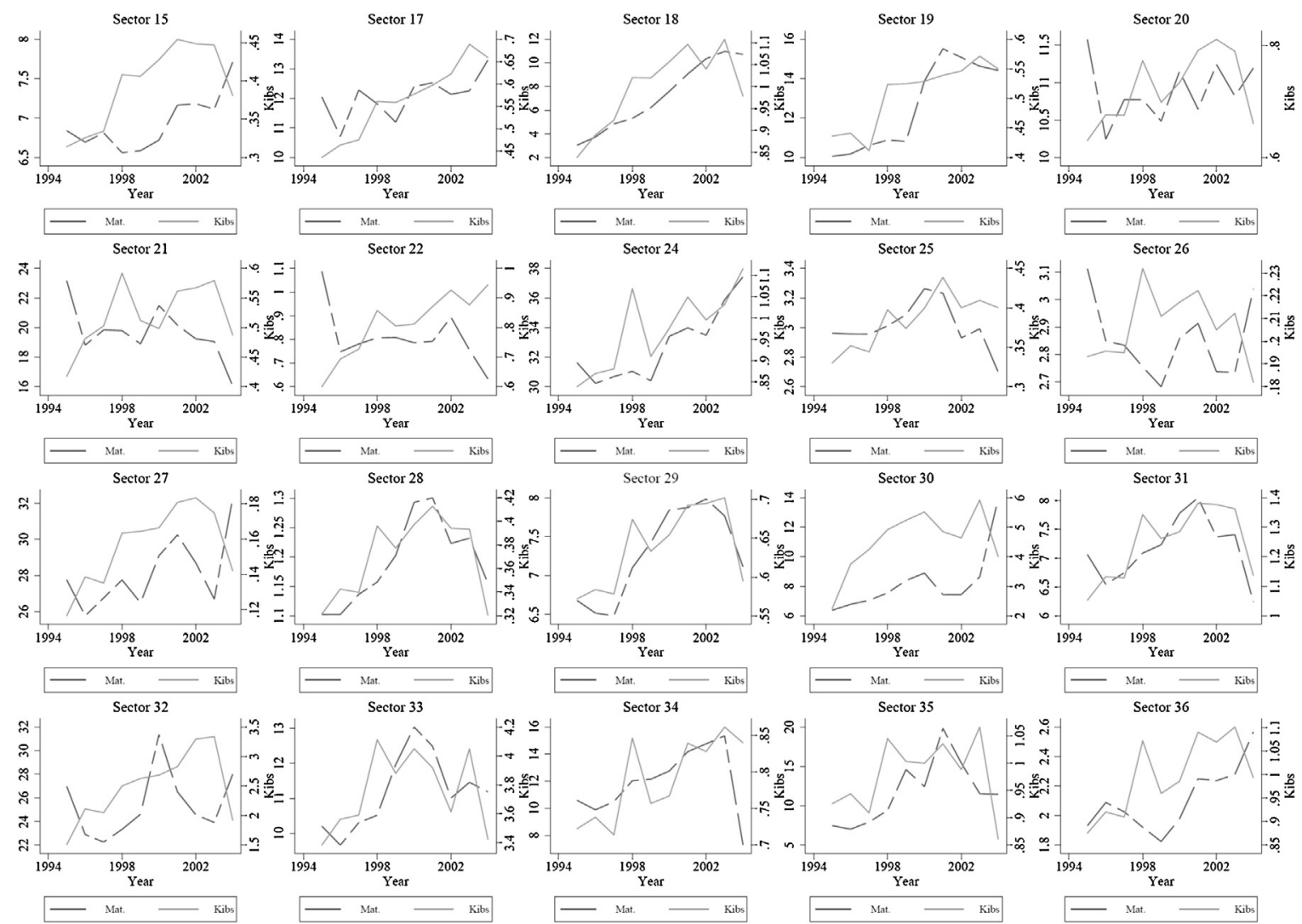

Fig. A.1. Evolution of material and service offshoring by 2 digit NACE manufacturing sector. Notes: The graphs present two scales, the one on the vertical axis on the left for material offshoring and the one on the right for offshoring of KIBS. Sector names are reported in Table A.2. Source: WITS-COMTRADE database and ISTAT. 

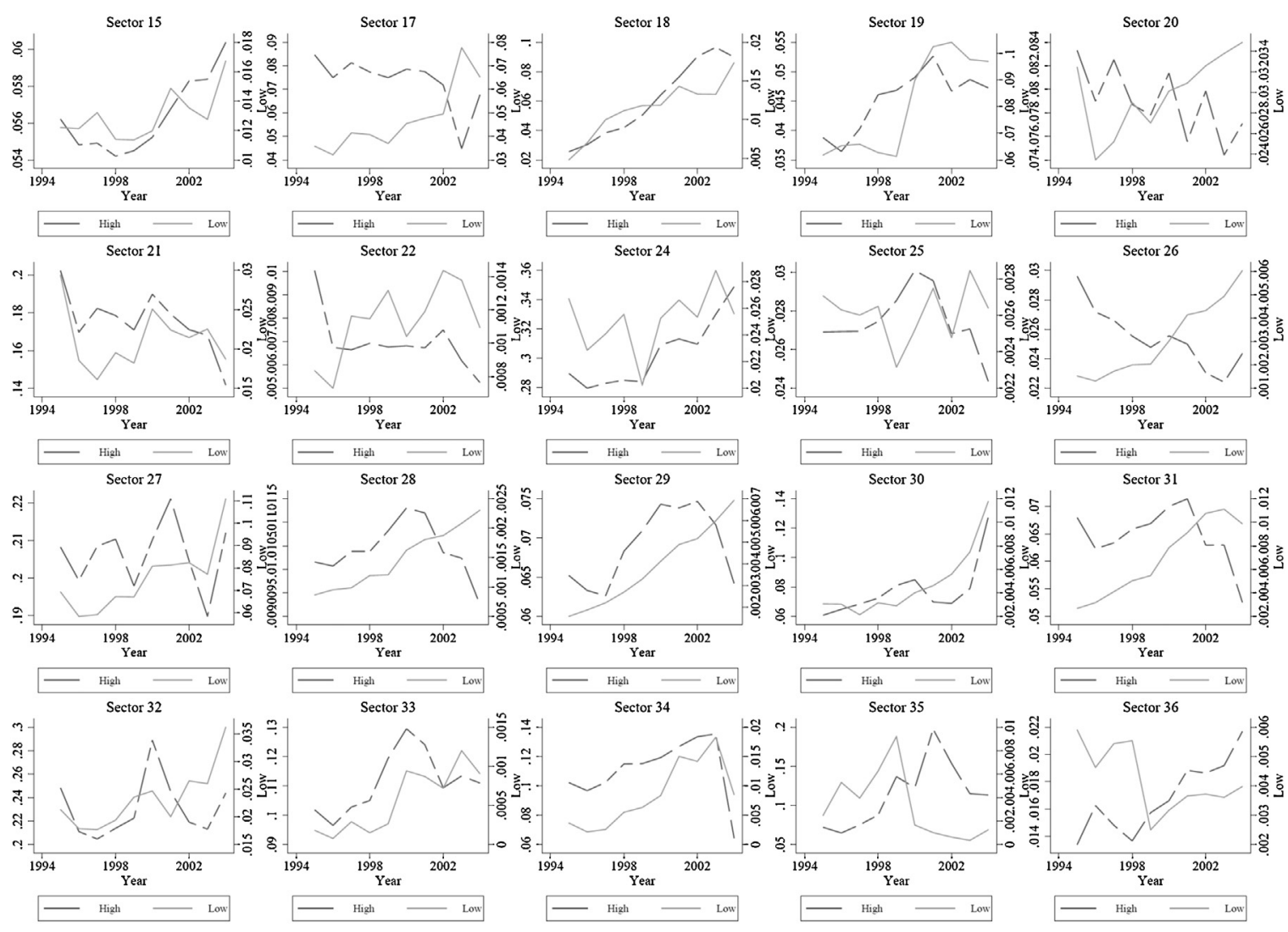

Fig. A.2. Offshoring evolution split by origin of material intermediates and 2 digit NACE manufacturing sector. Notes: The graphs present two scales, the one on the vertical axis on the left for material offshoring to high income countries and the one on the right for offshoring to low income countries. Sector names are reported in Table A.2.

Source: WITS-COMTRADE database and ISTAT. 
Table A.1

Definition of variables.

\begin{tabular}{|c|c|}
\hline Variable & Description \\
\hline Female & Dummy for the employees' gender. 1 for female, 0 for male. Source: ISFOL database \\
\hline Age & Age of the employee (in years). Source: ISFOL database \\
\hline WhiteCollar & Dummy for the skill level of job. 1 for white collar jobs, 0 for blue collar jobs. Source: ISFOL database \\
\hline Italian & Dummy for the employees' nationality. 1 for Italian workers, 0 for migrants. Source: ISFOL database \\
\hline $\ln ($ wage $)$ & Logarithm of the daily gross wage. Source: ISFOL database \\
\hline WorkExp & $\begin{array}{l}\text { Worker experience computed as the number of months the employee has worked till the start of the current job. } \\
\text { Source: ISFOL database }\end{array}$ \\
\hline PrevJobs & Number of previous jobs of the worker. Source: ISFOL database \\
\hline Quarter2 & Dummy with value 1 for workers hired in the months April-May-June. Source: ISFOL database \\
\hline Quarter3 & Dummy with value 1 for workers hired in the months July-August-September. Source: ISFOL database \\
\hline Quarter4 & Dummy with value 1 for workers hired in the months October-November-December. Source: ISFOL database \\
\hline FirmSize2 & Dummy with value 1 for workers employed in firms with more than 20 employees but less than 50. Source: ISFOL database \\
\hline FirmSize3 & Dummy with value 1 for workers employed in firms with more than 50 employees but less than 250 . Source: ISFOL database \\
\hline FirmSize4 & Dummy with value 1 for workers employed in firms with more than 250 employees but less than 550 . Source: ISFOL database \\
\hline FirmSize5 & Dummy with value 1 for workers employed in firms with more than 550 employees. Source: ISFOL database \\
\hline OFF Kibs & Offshoring of KIBS. Source: Istat and WITS-COMTRADE \\
\hline OFF narrow & Narrow indicator of offshoring of material intermediates. Source: Istat and WITS-COMTRADE \\
\hline OFF narrow & Narrow indicator of Offshoring of material intermediates to high income countries. Source: Istat and WITS-COMTRADE \\
\hline OFF narrow & Narrow indicator of offshoring of material intermediates to low income countries. Source: Istat and WITS-COMTRADE \\
\hline OFF broad & Broad indicator of offshoring of material intermediates. Source: Istat and WITS-COMTRADE \\
\hline OFF & Broad indicator of offshoring of material intermediates to high income countries. Source: Istat and WITS-COMTRADE \\
\hline OFF broad & Broad indicator of offshoring of material intermediates to low income countries. Source: Istat and WITS-COMTRADE \\
\hline $\mathrm{ImpPen}_{j}$ & Sectoral import penetration ratio. Source: Istat and WITS-COMTRADE \\
\hline Unemp reg & Regional unemployment rate. Source: Istat \\
\hline$L P_{j}$ & Logarithm of the sectoral labour productivity (value added/employment). Source: Istat \\
\hline$I C T_{j}$ & $\begin{array}{l}\text { Logarithm of the sectoral capital stock in office machines, telecommunication apparatus and software over the } \\
\text { total sectoral output. Source: Istat }\end{array}$ \\
\hline
\end{tabular}

Table A.2

Summary statistics of time-constant covariates fixed at job entry.

\begin{tabular}{|c|c|c|c|c|}
\hline & Mean & Std. Dev. & Min. & Max. \\
\hline Female & 0.324 & 0.468 & 0.000 & 1.000 \\
\hline Age & 31.112 & 8.359 & 20.000 & 50.000 \\
\hline WhiteCollar & 0.238 & 0.426 & 0.000 & 1.000 \\
\hline BlueCollar/Apprentice & 0.762 & 0.426 & 0.000 & 1.000 \\
\hline Italian & 0.965 & 0.183 & 0.000 & 1.000 \\
\hline $\ln$ (wage) & 4.006 & 0.444 & -3.553 & 7.759 \\
\hline WorkExp & 16.893 & 31.968 & 0.000 & 286.000 \\
\hline PrevJobs & 0.466 & 0.736 & 0.000 & 7.000 \\
\hline \multicolumn{5}{|l|}{ Quarter of entry in the sample } \\
\hline January-February-March & 0.336 & 0.472 & 0.000 & 1.000 \\
\hline April-May-June & 0.241 & 0.428 & 0.000 & 1.000 \\
\hline July-August-September & 0.195 & 0.396 & 0.000 & 1.000 \\
\hline October-November-December & 0.229 & 0.420 & 0.000 & 1.000 \\
\hline \multicolumn{5}{|l|}{ Area } \\
\hline North & 0.677 & 0.468 & 0.000 & 1.000 \\
\hline Centre & 0.168 & 0.374 & 0.000 & 1.000 \\
\hline South & 0.155 & 0.362 & 0.000 & 1.000 \\
\hline \multicolumn{5}{|l|}{ Sector } \\
\hline 15 - Food and beverage & 0.095 & 0.294 & 0.000 & 1.000 \\
\hline 17 - Textile & 0.060 & 0.238 & 0.000 & 1.000 \\
\hline 18 - Clothing & 0.070 & 0.255 & 0.000 & 1.000 \\
\hline 19 - Leather and leather products & 0.048 & 0.214 & 0.000 & 1.000 \\
\hline 20 - Lumber and wood (no furniture) & 0.032 & 0.177 & 0.000 & 1.000 \\
\hline 21 - Paper and paper products & 0.016 & 0.124 & 0.000 & 1.000 \\
\hline 22 - Editing and printing & 0.030 & 0.171 & 0.000 & 1.000 \\
\hline 24 - Chemicals & 0.047 & 0.211 & 0.000 & 1.000 \\
\hline 25 - Plastic materials and rubber & 0.046 & 0.210 & 0.000 & 1.000 \\
\hline 26 - Non-metallic mineral products & 0.055 & 0.228 & 0.000 & 1.000 \\
\hline 27 - Iron and steel & 0.029 & 0.168 & 0.000 & 1.000 \\
\hline 28 - Metallic products & 0.189 & 0.392 & 0.000 & 1.000 \\
\hline 29 - Machines & 0.096 & 0.294 & 0.000 & 1.000 \\
\hline 30 - Office machines & 0.014 & 0.119 & 0.000 & 1.000 \\
\hline 31 - Electrical machines & 0.051 & 0.219 & 0.000 & 1.000 \\
\hline
\end{tabular}




\begin{tabular}{|c|c|c|c|c|}
\hline & Mean & Std. Dev. & Min. & Max. \\
\hline 32 - Broadcasting and communications equipment & 0.025 & 0.155 & 0.000 & 1.000 \\
\hline 33 - Surgical and medical instruments & 0.021 & 0.144 & 0.000 & 1.000 \\
\hline 34 - Vehicles & 0.024 & 0.152 & 0.000 & 1.000 \\
\hline 35 - Other vehicles & 0.013 & 0.114 & 0.000 & 1.000 \\
\hline 36 - Furniture and other manufacturing industries & 0.038 & 0.190 & 0.000 & 1.000 \\
\hline \multicolumn{5}{|l|}{ Firm size in number of employees } \\
\hline$(0,20]$ & 0.362 & 0.481 & 0.000 & 1.000 \\
\hline$(20,49]$ & 0.152 & 0.359 & 0.000 & 1.000 \\
\hline$(49,249]$ & 0.212 & 0.409 & 0.000 & 1.000 \\
\hline$(249,549]$ & 0.061 & 0.240 & 0.000 & 1.000 \\
\hline 550 or more & 0.213 & 0.410 & 0.000 & 1.000 \\
\hline$\#$ of individuals $N$ & \multicolumn{4}{|c|}{19,259} \\
\hline
\end{tabular}

Source: ISFOL database.

Table A.3

Summary statistics of time-varying covariates at sampling date.

\begin{tabular}{|c|c|c|c|c|}
\hline & Mean & Std. Dev. & Min. & Max. \\
\hline OFF $F_{\text {Kibs }}$ & 0.69 & 0.67 & 0.12 & 4.92 \\
\hline OFF narrow & 7.91 & 7.87 & 0.75 & 31.63 \\
\hline OFF narrow $_{\text {High }}$ & 6.62 & 6.92 & 0.66 & 28.96 \\
\hline OFF narrow & 1.29 & 1.80 & 0.01 & 6.93 \\
\hline OFF broad & 19.82 & 9.10 & 8.88 & 54.82 \\
\hline$O F F_{\text {broad }}^{\text {High }}$ & 16.74 & 8.73 & 7.48 & 50.69 \\
\hline OFF broad & 3.09 & 1.71 & 0.90 & 7.74 \\
\hline $\operatorname{ImpPen}_{j}$ & 22.64 & 24.56 & 1.11 & 129.21 \\
\hline Unemp $p^{\text {reg }}$ & 0.09 & 0.05 & 0.04 & 0.24 \\
\hline$L P_{j}$ & 3.59 & 0.28 & 2.69 & 4.31 \\
\hline$I C T_{j}$ & -10.70 & 0.86 & -11.95 & -7.47 \\
\hline$\#$ of individuals $N$ & \multicolumn{4}{|c|}{19,259} \\
\hline
\end{tabular}

Source: WITS-COMTRADE database and ISTAT.

Table A.4

Pairwise correlations.

\begin{tabular}{|c|c|c|c|c|c|c|c|c|c|c|c|}
\hline & OFF $F_{\text {narrow }}$ & OFF broad & $O F F_{K i b s}$ & OFF $F_{\text {narrow }}^{\text {High }}$ & OFF $F_{\text {narrow }}^{\text {Low }}$ & OFF $F_{\text {broad }}^{\text {High }}$ & OFF $F_{\text {broad }}^{\text {Low }}$ & ImpPen $_{j}$ & Unemp $^{\text {reg }}$ & $L P_{j}$ & $I C T_{j}$ \\
\hline OFF narrow & 1.000 & & & & & & & & & & \\
\hline$O F F_{\text {broad }}$ & 0.623 & 1.000 & & & & & & & & & \\
\hline OFF & 0.170 & 0.649 & 1.000 & & & & & & & & \\
\hline $\mathrm{OFF}_{\text {narrow }}^{\text {High }}$ & 0.978 & 0.658 & 0.230 & 1.000 & & & & & & & \\
\hline OFF $F_{\text {narrow }}^{\text {Law }}$ & 0.592 & 0.180 & -0.145 & 0.409 & 1.000 & & & & & & \\
\hline$O F F^{H i g h}$ & 0.592 & 0.984 & 0.674 & 0.658 & 0.045 & 1.000 & & & & & \\
\hline OFF Lroad & 0.311 & 0.313 & 0.012 & 0.152 & 0.770 & 0.140 & 1.000 & & & & \\
\hline ImpPen $_{j}$ & 0.105 & 0.096 & 0.115 & 0.159 & -0.153 & 0.143 & -0.231 & 1.000 & & & \\
\hline Unemp $^{\text {reg }}$ & -0.008 & -0.012 & 0.038 & -0.004 & -0.021 & -0.006 & -0.033 & -0.065 & 1.000 & & \\
\hline$L P_{j}$ & 0.527 & 0.392 & 0.053 & 0.603 & -0.024 & 0.463 & -0.292 & 0.338 & -0.069 & 1.000 & \\
\hline$I C T_{j}$ & 0.247 & 0.674 & 0.827 & 0.311 & -0.119 & 0.695 & 0.042 & 0.026 & 0.018 & 0.077 & 1.000 \\
\hline
\end{tabular}

All correlations are significant at the $1 \%$ level.

\section{Appendix B. Supplementary data}

Supplementary data associated with this article can be found, in the online version, at doi:http://dx.doi.org/ 10.1016/j.strueco.2013.04.001.

\section{References}

Amiti, M., Wei, S., 2004. Fear of service outsourcing: is it justified? NBER Working Papers 10808. National Bureau of Economic Research, Inc.

Arndt, S.W., 1997. Globalization and the open economy. The North American Journal of Economics and Finance 8 (1), 71-79.

Bachmann, R., Braun, S., 2011. The impact of international outsourcing on labour market dynamics in Germany. Scottish Journal of Political Economy 58 (1), 1-28.
Baker, M., Melino, A., 2000. Duration dependence and nonparametric heterogeneity: a Monte Carlo study. Journal of Econometrics 96 (2), 357-393.

Baumgarten, D., 2009. International outsourcing, the nature of tasks, and occupational stability. Empirical evidence for Germany. Ruhr Economic Papers 0108. Rheinisch-Westfälisches Institut für Wirtschaftsforschung, Ruhr-Universität Bochum, Universität Dortmund, Universität Duisburg-Essen.

Brinch, C.N., 2007. Nonparametric identification of the mixed hazards model with time-varying covariates. Econometric Theory 23 (2), 349-354.

Cadarso, M.A., Gomez, N., Lopez, L.A., Tobarra, M.A., 2008. The EU enlargement and the impact of outsourcing on industrial employment in Spain, 1993-2003. Structural Change and Economic Dynamics 19 (1), 95-108.

Centra, M., Rustichelli, E., 2005. La costruzione del panel longitudinale isfol. Monografie ISFOL. 
Cockx, B., abd Picchio, M., 2012. Are short-lived jobs stepping stones to long-lasting jobs? Oxford Bulletin of Economics and Statistics 74 (5), 646-675.

Davidson, C., Matusz, S.J., 2005. Trade and turnover: theory and evidence. Review of International Economics 13 (5), 861-880.

Davis, D.R., Harrigan, J., 2007. Good jobs, bad jobs, and trade liberalization. NBER Working Papers 13139. National Bureau of Economic Research, Inc.

Davies, S.J., Haltiwanger, J., 1999. Gross job flows. In: Ashenfelter, O., Card, D. (Eds.), In: Handbook of Labor Economics. Handbook of Labor Economics, vol. 3. Elsevier, pp. 2711-2805.

Dutt, P., Mitra, D., Ranjan, P., 2009. International trade and unemployment: theory and cross-national evidence. Journal of International Economics 78 (1), 32-44.

Egger, H., Falkinger, J., 2001. A complete characterization of the distributional effects of international outsourcing in the Heckscher-Ohlin model. CESifo Working Paper Series 573. CESifo Group, Munich.

Egger, H., Kreickemeier, U., 2009. Firm heterogeneity and the labor market effects of trade liberalization. International Economic Review 50 (1), 187-216.

Egger, H., Kreickemeier, U., 2010. Worker-specific effects of globalisation. World Economy 33 (8), 987-1005.

Egger, P., Pfaffermayr, M., Weber, A., 2007. Sectoral adjustment of employment to shifts in outsourcing and trade: evidence from a dynamic fixed effects multinomial logit model. Journal of Applied Econometrics 22 (3), 559-580.

Elbers, C., Ridder, G., 1982. True and spurious duration dependence: the identifiability of the proportional hazard model. Review of Economic Studies 49 (3), 403-409.

Falk, M., Wolfmayr, Y., 2008. Services and materials outsourcing to low-wage countries and employment: empirical evidence from EU countries. Structural Change and Economic Dynamics 19 (1), 38-52.

Farber, H., 1999. Mobility and stability: the dynamics of job change in labor markets. In: Ashenfelter, O., Card, D. (Eds.), In: Handbook of Labor Economics, vol. 3B. Elsevier Science, Amsterdam, pp. 2439-2483 (Chapter 37)

Feenstra, R.C., Hanson, G.H., 1996. Globalization, outsourcing, and wage inequality. American Economic Review 86 (2), 240-245.

Feenstra, R.C., Hanson, G.H., 1999. The impact of outsourcing and high-technology capital on wages: estimates for the United States, 1979-1990. Quarterly Journal of Economics 114 (3), 907-940.

Felbermayr, G., Prat, J., Schmerer, H.-J., 2008. Globalization and labor market outcomes: wage bargaining, search frictions, and firm heterogeneity. IZA Discussion Papers 3363. Institute for the Study of Labor (IZA).

Fitzgerald, D., Hallak, J.C., 2004. Specialization, factor accumulation and development. Journal of International Economics 64 (2), 277-302.

Flinn, C., Heckman, J.J., 1982. Models for the analysis of labor force dynamics. In: Basmann, R., Rhodes, G. (Eds.), Advances in Econometrics. JAI Press, Greenwich, pp. 35-95.

Gaure, S., Røed, K., Zhang, T., 2007. Time and causality: a Monte Carlo assessment of the timing-of-events approach. Journal of Econometrics 141 (2), 1159-1195.
Geishecker, I., 2008. The impact of international outsourcing on individual employment security: a micro-level analysis. Labour Economics, 291-314.

Goldberg, L., Tracy, J., Aaronson, S., 1999. Exchange rates and employment instability: evidence from matched CPS data. American Economic Review 89 (2), 204-210.

Grossman, G.M., Rossi-Hansberg, E., 2008. Trading tasks: a simple theory of offshoring. American Economic Review 98 (5), 1978-1997.

Harrison, A., McMillan, M., 2007. Offshoring jobs? Multinationals and U.S. manufacturing employment. Tech. Rep. 48, IPC Working Paper Series.

Heckman, J.J., Singer, B., 1984. A method for minimizing the impact of distributional assumptions in econometric models for duration data. Econometrica 52 (2), 271-320.

Helpman, E., Itskhoki, O., 2010. Labour market rigidities, trade and unemployment. Review of Economic Studies 77 (3), 1100-1137.

Hungerford, T.L., 1995. International trade, comparative advantage and the incidence of layoff unemployment spells. Review of Economics and Statistics 77 (3), 511-521.

Jovanovic, B., 1979. Job matching and the theory of turnover. Journal of Political Economy 85 (5), 972-990.

Klein, M.W., Schuh, S., Triest, R.K., 2002. Job creation, job destruction, and international competition: a literature review. Working Papers 02-7. Federal Reserve Bank of Boston.

Kletzer, L.G., 2000. Trade and job loss in US manufacturing, 1979-1994. In: The Impact of International Trade on Wages. NBER Chapters. National Bureau of Economic Research, Inc., pp. 349-396.

Kruse, D.L., 1988. International trade and the labor market experience of displaced workers. Industrial and Labor Relations Review 41 (3), 402-417.

Lo Turco, A., Maggioni, D., 2012. Offshoring to high and low income countries and the labour demand. Evidence from Italian Firms. Review of International Economics 20 (3), 636-653.

Mitra, D., Ranjan, P., 2007. Offshoring and unemployment. NBER Working Papers 13149. National Bureau of Economic Research, Inc.

Mitra, D., Ranjan, P., 2010. Offshoring and unemployment: the role of search frictions labor mobility. Journal of International Economics 81 (2), 219-229.

Munch, J.R., 2010. Whose job goes abroad? international outsourcing and individual job separations. Scandinavian Journal of Economics $112(2)$ 339-360.

Nucci, F., Pozzolo, A.F., 2010. The exchange rate, employment and hours: what firm-level data say. Journal of International Economics 82 (2), $112-123$.

OECD, 2007. Offshoring and Employment: Trends and Impacts. OECD, Paris.

Schott, P., 2003. One size fits all? Heckscher-Ohlin specialization in global production. American Economic Review 93 (3), 686-708.

Schott, P.K., 2004. Across-product versus within-product specialization in international trade. Quarterly Journal of Economics 119 (2), 646-677.

Topel, R., Ward, M., 1992. Job mobility and the careers of young men. Quarterly Journal of Economics 107 (2), 439-479.

van den Berg, G.J., van der Klaauw, B., 2001. Combining micro and macro unemployment duration data. Journal of Econometrics 102 (2), 271-309. 